\title{
Silver Nanoparticles: Synthesis, Characterization, Properties, Applications, and Therapeutic Approaches
}

\author{
Xi-Feng Zhang ${ }^{1}$, Zhi-Guo Liu ${ }^{1}$, Wei Shen ${ }^{2}$ and Sangiliyandi Gurunathan ${ }^{3, *}$ \\ 1 College of Biological and Pharmaceutical Engineering, Wuhan Polytechnic University, Wuhan 430023, China; \\ zhangxf9465@163.com (X.-F.Z.); zhiguo_1@126.com (Z.-G.L.) \\ 2 Key Laboratory of Animal Reproduction and Germplasm Enhancement in Universities of Shandong, \\ College of Animal Science and Technology, Qingdao Agricultural University, Qingdao 266109, China; \\ shenwei427@126.com \\ 3 Department of Stem Cell and Regenerative Biotechnology, Konkuk University, Seoul 143-701, Korea \\ * Correspondence: gsangiliyandi@yahoo.com; Tel.: +82-2-450-0457; Fax: +82-2-544-4645
}

Academic Editor: Bing Yan

Received: 5 July 2016; Accepted: 1 September 2016; Published: 13 September 2016

\begin{abstract}
Recent advances in nanoscience and nanotechnology radically changed the way we diagnose, treat, and prevent various diseases in all aspects of human life. Silver nanoparticles (AgNPs) are one of the most vital and fascinating nanomaterials among several metallic nanoparticles that are involved in biomedical applications. AgNPs play an important role in nanoscience and nanotechnology, particularly in nanomedicine. Although several noble metals have been used for various purposes, AgNPs have been focused on potential applications in cancer diagnosis and therapy. In this review, we discuss the synthesis of AgNPs using physical, chemical, and biological methods. We also discuss the properties of AgNPs and methods for their characterization. More importantly, we extensively discuss the multifunctional bio-applications of AgNPs; for example, as antibacterial, antifungal, antiviral, anti-inflammatory, anti-angiogenic, and anti-cancer agents, and the mechanism of the anti-cancer activity of AgNPs. In addition, we discuss therapeutic approaches and challenges for cancer therapy using AgNPs. Finally, we conclude by discussing the future perspective of AgNPs.
\end{abstract}

Keywords: silver nanoparticles; synthesis; characterization; applications; mechanisms; cancer therapy

\section{Introduction}

Silver nanoparticles (AgNPs) are increasingly used in various fields, including medical, food, health care, consumer, and industrial purposes, due to their unique physical and chemical properties. These include optical, electrical, and thermal, high electrical conductivity, and biological properties [1-3]. Due to their peculiar properties, they have been used for several applications, including as antibacterial agents, in industrial, household, and healthcare-related products, in consumer products, medical device coatings, optical sensors, and cosmetics, in the pharmaceutical industry, the food industry, in diagnostics, orthopedics, drug delivery, as anticancer agents, and have ultimately enhanced the tumor-killing effects of anticancer drugs [4]. Recently, AgNPs have been frequently used in many textiles, keyboards, wound dressings, and biomedical devices $[2,5,6]$. Nanosized metallic particles are unique and can considerably change physical, chemical, and biological properties due to their surface-to-volume ratio; therefore, these nanoparticles have been exploited for various purposes $[7,8]$. In order to fulfill the requirement of AgNPs, various methods have been adopted for synthesis. Generally, conventional physical and chemical methods seem to be very expensive and hazardous [1,9]. Interestingly, biologically-prepared AgNPs show high yield, solubility, and high stability [1]. Among several synthetic methods for AgNPs, biological methods seem to be simple, rapid, non-toxic, dependable, and green approaches that can produce well-defined size and 
morphology under optimized conditions for translational research. In the end, a green chemistry approach for the synthesis of AgNPs shows much promise.

After synthesis, precise particle characterization is necessary, because the physicochemical properties of a particle could have a significant impact on their biological properties. In order to address the safety issue to use the full potential of any nano material in the purpose of human welfare, in nanomedicines, or in the health care industry, etc., it is necessary to characterize the prepared nanoparticles before application $[10,11]$. The characteristic feature of nanomaterials, such as size, shape, size distribution, surface area, shape, solubility, aggregation, etc. need to be evaluated before assessing toxicity or biocompatibility [12]. To evaluate the synthesized nanomaterials, many analytical techniques have been used, including ultraviolet visible spectroscopy (UV-vis spectroscopy), X-ray diffractometry (XRD), Fourier transform infrared spectroscopy (FTIR), X-ray photoelectron spectroscopy (XPS), dynamic light scattering (DLS), scanning electron microscopy (SEM), transmission electron microscopy (TEM), atomic force microscopy (AFM), and so on [13,14].

The biological activity of AgNPs depends on factors including surface chemistry, size, size distribution, shape, particle morphology, particle composition, coating/capping, agglomeration, and dissolution rate, particle reactivity in solution, efficiency of ion release, and cell type, and the type of reducing agents used for the synthesis of AgNPs are a crucial factor for the determination of cytotoxicity [15]. The physicochemical properties of nanoparticles enhance the bioavailability of therapeutic agents after both systemic and local administration $[16,17]$ and other hand it can affect cellular uptake, biological distribution, penetration into biological barriers, and resultant therapeutic effects [18,19]. Therefore, the development of AgNPs with controlled structures that are uniform in size, morphology, and functionality are essential for various biomedical applications [20-24].

Cancer is a complex, multifactorial disease which has the characteristic feature of the uncontrolled growth and spread of abnormal cells caused by several factors, including a combination of genetic, external, internal, and environmental factors [25], and it is treated by various treatments including chemotherapy, hormone therapy, surgery, radiation, immune therapy, and targeted therapy [25]. Therefore, the challenge is to identify effective, cost-effective, and sensitive lead molecules that have cell-targeted specificity and increase the sensitivity. Recently, AgNPs have been shown much interest because of their therapeutic applications in cancer as anticancer agents, in diagnostics, and in probing. Taken literature into consideration, in this review we focused on recent developments in synthesis, characterization, properties, and bio-applications mainly on the antibacterial, antifungal, antiviral, anti-inflammatory, anti-cancer and anti-angiogenic properties of AgNPs in a single platform. This review also emphasizes mechanism of anticancer activity, therapeutic approaches and the challenges and limitations of nanoparticles in cancer therapy. Finally, this review ends with conclusion and the future perspective of AgNPs.

\section{Synthesis of AgNPs}

\subsection{Synthesis of AgNPs Using Physical and Chemical Methods}

Generally, the synthesis of nanoparticles has been carried out using three different approaches, including physical, chemical, and biological methods. In physical methods, nanoparticles are prepared by evaporation-condensation using a tube furnace at atmospheric pressure [26-29]. Conventional physical methods including spark discharging and pyrolysis were used for the synthesis of AgNPs [30,31]. The advantages of physical methods are speed, radiation used as reducing agents, and no hazardous chemicals involved, but the downsides are low yield and high energy consumption, solvent contamination, and lack of uniform distribution [32-36].

Chemical methods use water or organic solvents to prepare the silver nanoparticles [37,38]. This process usually employs three main components, such as metal precursors, reducing agents, and stabilizing/capping agents. Basically, the reduction of silver salts involves two stages (1) nucleation; and (2) subsequent growth. In general, silver nanomaterials can be obtained by two methods, classified 
as "top-down" and "bottom-up" [39]. The "top-down" method is the mechanical grinding of bulk metals with subsequent stabilization using colloidal protecting agents [40,41]. The "bottom-up" methods include chemical reduction, electrochemical methods, and sono-decomposition. The major advantage of chemical methods is high yield, contrary to physical methods, which have low yield. The above-mentioned methods are extremely expensive. Additionally, the materials used for AgNPs synthesis, such as citrate, borohydride, thio-glycerol, and 2-mercaptoethanol are toxic and hazardous [41]. Apart from these disadvantages, the manufactured particles are not of expected purity, as their surfaces were found to be sedimented with chemicals. It is also very difficult to prepare AgNPs with a well-defined size, requiring a further step for the prevention of particle aggregation [42]. In addition, during the synthesis process, too many toxic and hazardous byproducts are excised out. Chemical methods make use of techniques such as cryochemical synthesis [43], laser ablation [44], lithography [45], electrochemical reduction [46], laser irradiation [47], sono-decomposition [48], thermal decomposition [49], and chemical reduction [50]. The advantage of the chemical synthesis of nanoparticles are the ease of production, low cost, and high yield; however, the use of chemical reducing agents are harmful to living organisms [13]. Recently, Abbasi et al. explained a detailed account of synthesis methods, properties, and bio-application of AgNPs [51].

\subsection{Green Chemistry Approach for the Synthesis of AgNPs}

To overcome the shortcomings of chemical methods, biological methods have emerged as viable options. Recently, biologically-mediated synthesis of nanoparticles have been shown to be simple, cost effective, dependable, and environmentally friendly approaches and much attention has been given to the high yield production of AgNPs of defined size using various biological systems including bacteria, fungi, plant extracts, and small biomolecules like vitamins and amino acids as an alternative method to chemical methods-not only for AgNPs, but also for the synthesis of several other nanoparticles, such as gold and graphene [9,52-56]. Bio-sorption of metals by Gram-negative and Gram-positive bacteria provided an indication for the synthesis of nanoparticles before the flourishing of this biological method; however, the synthesized nanomaterials were as aggregates not nanoparticles [57]. Several studies reported the synthesis of AgNPs using green, cost effective, and biocompatible methods without the use of toxic chemicals in biological methods. In this green chemistry approach, several bacteria, including Pseudomonas stutzeri AG259 [58], Lactobacillus strains [59], Bacillus licheniformis [55]; Escherichia coli (E. coli) [9], Brevibacterium casei [60], fungi including Fusarium oxysporum [61], Ganoderma neo-japonicum Imazeki [62], plant extracts such as Allophylus cobbe [52], Artemisia princeps [63], and Typha angustifolia [64] were utilized. In addition to these, several biomolecules, such as biopolymers [65], starch [66], fibrinolytic enzyme [39], and amino acids [67] were used. The biological synthesis of nanoparticles depends on three factors, including (a) the solvent; (b) the reducing agent; and (c) the non-toxic material. The major advantage of biological methods is the availability of amino acids, proteins, or secondary metabolites present in the synthesis process, the elimination of the extra step required for the prevention of particle aggregation, and the use of biological molecules for the synthesis of AgNPs is eco-friendly and pollution-free. Biological methods seem to provide controlled particle size and shape, which is an important factor for various biomedical applications [68]. Using bacterial protein or plant extracts as reducing agents, we can control the shape, size, and monodispersity of the nanoparticles [9]. The other advantages of biological methods are the availability of a vast array of biological resources, a decreased time requirement, high density, stability, and the ready solubility of prepared nanoparticles in water [69].

The biological activity of AgNPs depends on the morphology and structure of AgNPs, controlled by size and shape of the particles [70,71]. As far as size and shape are concerned, smaller size and truncated-triangular nanoparticles seem to be more effective and have superior properties. Although many studies successfully synthesized AgNPs with different shape and size ranges, they still have certain limitations. To achieve control over morphology and structure, an excess of strong reducing agent such as sodium borohydride $\left(\mathrm{NaBH}_{4}\right)$ was used for the synthesis of monodisperse and 
uniform-sized silver colloids [72]. Compared to chemical methods, biological methods allow for more ease in the control of shape, size, and distribution of the produced nanoparticles by optimization of the synthesis methods, including the amount of precursors, temperature, $\mathrm{pH}$, and the amount of reducing and stabilizing factors $[9,73]$.

\section{Characterization}

The physicochemical properties of nanoparticles are important for their behavior, bio-distribution, safety, and efficacy. Therefore, characterization of AgNPs is important in order to evaluate the functional aspects of the synthesized particles. Characterization is performed using a variety of analytical techniques, including UV-vis spectroscopy, X-ray diffractometry (XRD), Fourier transform infrared spectroscopy (FTIR), X-ray photoelectron spectroscopy (XPS), dynamic light scattering (DLS), scanning electron microscopy (SEM), transmission electron microscopy (TEM), and atomic force microscopy (AFM). Several qualified books and reviews have presented the principles and usage of various kinds of analytical techniques for the characterization of AgNPs; however, the basics of the important techniques used for the characterization of AgNPs are detailed below for ease of understanding. For example, characterization of AgNPs using various analytical techniques prepared from culture supernatant of Bacillus species was given in Figure 1.
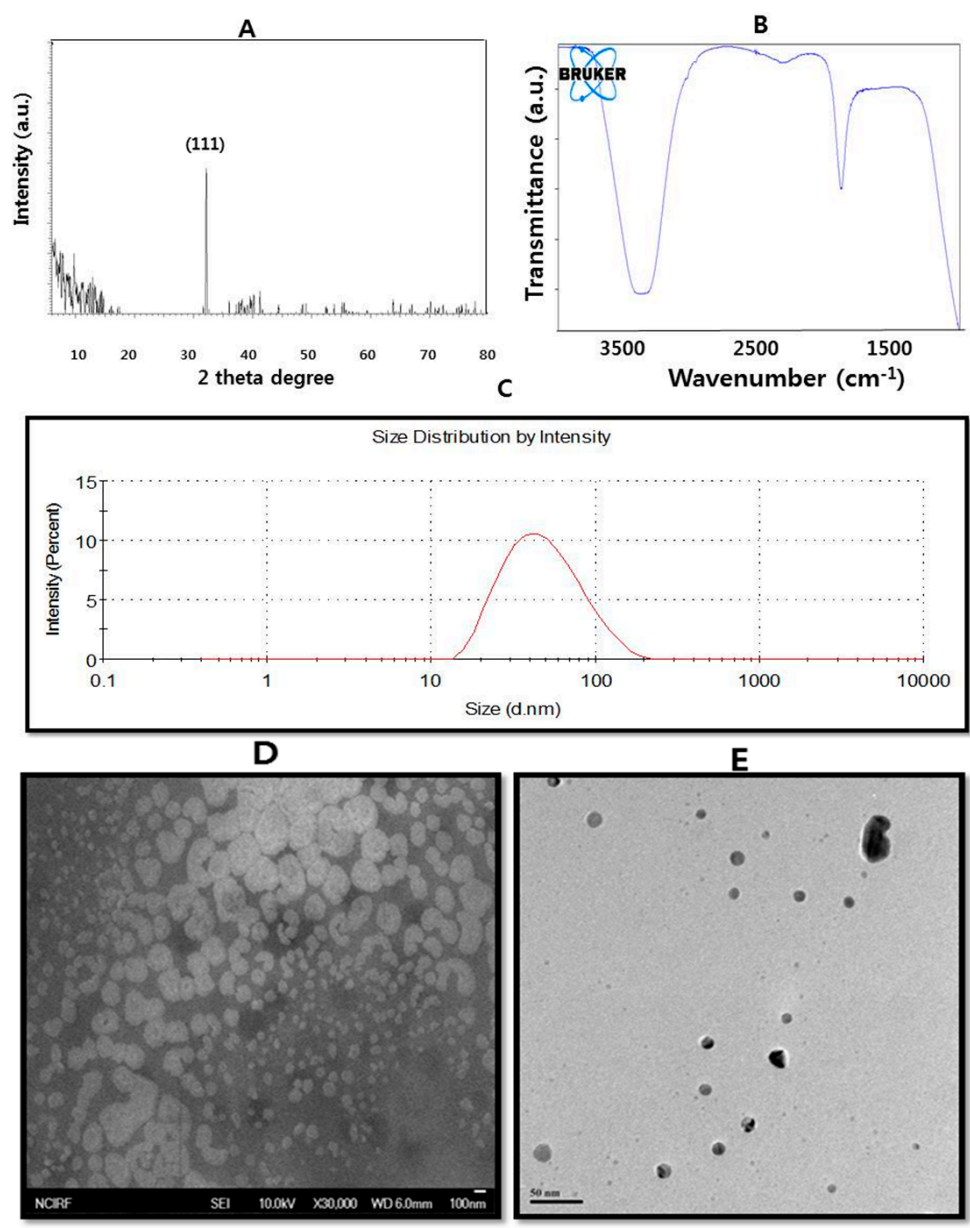

Figure 1. Characterization of silver nanoparticles (AgNPs) prepared from Bacillus species using various analytical techniques. (A) Characterization of AgNPs by X-diffraction spectra of AgNPs; (B) Fourier transform infrared spectra of AgNPs; (C) Measurement of size distribution of AgNPs by dynamic light scattering; (D) Scanning electron microscopy images of AgNPs; (E). Transmission electron microscopy images of AgNPs. 


\subsection{UV-Visible Spectroscopy}

UV-vis spectroscopy is a very useful and reliable technique for the primary characterization of synthesized nanoparticles which is also used to monitor the synthesis and stability of AgNPs [74]. AgNPs have unique optical properties which make them strongly interact with specific wavelengths of light [75]. In addition, UV-vis spectroscopy is fast, easy, simple, sensitive, selective for different types of NPs, needs only a short period time for measurement, and finally a calibration is not required for particle characterization of colloidal suspensions [76-78]. In AgNPs, the conduction band and valence band lie very close to each other in which electrons move freely. These free electrons give rise to a surface plasmon resonance (SPR) absorption band, occurring due to the collective oscillation of electrons of silver nano particles in resonance with the light wave [79-84]. The absorption of AgNPs depends on the particle size, dielectric medium, and chemical surroundings [81-85]. Observation of this peak-assigned to a surface plasmon-is well documented for various metal nanoparticles with sizes ranging from 2 to $100 \mathrm{~nm}[74,86,87]$. The stability of AgNPs prepared from biological methods was observed for more than 12 months, and an SPR peak at the same wavelength using UV-vis spectroscopy was observed.

\subsection{X-ray Diffraction (XRD)}

$\mathrm{X}$-ray diffraction $(\mathrm{XRD})$ is a popular analytical technique which has been used for the analysis of both molecular and crystal structures [79,88], qualitative identification of various compounds [89], quantitative resolution of chemical species [90], measuring the degree of crystallinity [91], isomorphous substitutions [92], particle sizes [93], etc. When X-ray light reflects on any crystal, it leads to the formation of many diffraction patterns, and the patterns reflect the physico-chemical characteristics of the crystal structures. In a powder specimen, diffracted beams typically come from the sample and reflect its structural physico-chemical features. Thus, XRD can analyze the structural features of a wide range of materials, such as inorganic catalysts, superconductors, biomolecules, glasses, polymers, and so on [94]. Analysis of these materials largely depends on the formation of diffraction patterns. Each material has a unique diffraction beam which can define and identify it by comparing the diffracted beams with the reference database in the Joint Committee on Powder Diffraction Standards (JCPDS) library. The diffracted patterns also explain whether the sample materials are pure or contain impurities. Therefore, XRD has long been used to define and identify both bulk and nanomaterials, forensic specimens, industrial, and geochemical sample materials [95-104].

$\mathrm{XRD}$ is a primary technique for the identification of the crystalline nature at the atomic scale $[10,14,88,105]$. X-ray powder diffraction is a nondestructive technique with great potential for the characterization of both organic and inorganic crystalline materials [106]. This method has been used to measure phase identification, conduct quantitative analysis, and to determine structure imperfections in samples from various disciplines, such as geological, polymer, environmental, pharmaceutical, and forensic sciences. Recently, the applications have extended to the characterization of various nano-materials and their properties [106]. The working principle of X-ray diffraction is Bragg's law $[88,105]$. Typically, XRD is based on the wide-angle elastic scattering of X-rays [10,14,88,107-109]. Although XRD has several merits, it has limited disadvantages, including difficulty in growing the crystals and the ability to get results pertaining only to single conformation/binding state $[14,108,110]$. Another drawback of XRD is the low intensity of diffracted X-rays compared to electron diffractions [110,111].

\subsection{Dynamic Light Scattering}

Physicochemical characterization of prepared nanomaterials is an important factor for the analysis of biological activities using radiation scattering techniques [10,14,112]. DLS can probe the size distribution of small particles a scale ranging from submicron down to one nanometer in solution or suspension $[10,14,113]$. Dynamic light scattering is a method that depends on the interaction of light 
with particles. This method can be used for the measurement of narrow particle size distributions, especially in the range of 2-500 $\mathrm{nm}$ [78]. Among the techniques for the characterization of nanoparticles, the most commonly used is DLS [114-116]. DLS measures the light scattered from a laser that passes through a colloid, and mostly relies on Rayleigh scattering from the suspended nanoparticles [117]. Next, the modulation of the scattered light intensity as a function of time is analyzed, and the hydrodynamic size of particles can be determined [118-120]. To evaluate the toxic potential of any nanomaterial, its characterization in solution is essential [11]. Therefore; DLS is mainly used to determine particle size and size distributions in aqueous or physiological solutions [12]. The size obtained from DLS is usually larger than TEM, which may be due to the influence of Brownian motion. DLS is a nondestructive method used to obtain the average diameter of nanoparticles dispersed in liquids. It has the special advantage of probing a large quantity of particles simultaneously; however, it has a number of sample-specific limitations [101,121].

\subsection{Fourier Transform Infrared (FTIR) Spectroscopy}

FTIR is able to provide accuracy, reproducibility, and also a favorable signal-to-noise ratio. By using FTIR spectroscopy, it becomes possible to detect small absorbance changes on the order of $10^{-3}$, which helps to perform difference spectroscopy, where one could distinguish the small absorption bands of functionally active residues from the large background absorption of the entire protein [122-128]. FTIR spectroscopy is frequently used to find out whether biomolecules are involved in the synthesis of nanoparticles, which is more pronounced in academic and industrial research $[10,68,129,130]$. Furthermore, FTIR has also been extended to the study of nano-scaled materials, such as confirmation of functional molecules covalently grafted onto silver, carbon nanotubes, graphene and gold nanoparticles, or interactions occurring between enzyme and substrate during the catalytic process $[68,131,132]$. Furthermore, it is a non-invasive technique. Finally, the advantages of FTIR spectrometers over dispersive ones are rapid data collection, strong signal, large signal-to-noise ratio, and less sample heat-up [133]. Recently, further advancement has been made in an FTIR method called attenuated total reflection (ATR)-FTIR spectroscopy [134-136]. Using ATR-FTIR, we can determine the chemical properties on the polymer surface, and sample preparation is easy compared to conventional FTIR [10,137-141]. Therefore, FTIR is a suitable, valuable, non-invasive, cost effective, and simple technique to identify the role of biological molecules in the reduction of silver nitrate to silver.

\subsection{X-ray Photoelectron Spectroscopy (XPS)}

XPS is a quantitative spectroscopic surface chemical analysis technique used to estimate empirical formulae [109,140-142]. XPS is also known as electron spectroscopy for chemical analysis (ESCA), [141]. XPS plays a unique role in giving access to qualitative, quantitative/semi-quantitative, and speciation information concerning the sensor surface [143]. XPS is performed under high vacuum conditions. $X$-ray irradiation of the nanomaterial leads to the emission of electrons, and the measurement of the kinetic energy and the number of electrons escaping from the surface of the nanomaterials gives XPS spectra [109,140-142]. The binding energy can be calculated from kinetic energy. Specific groups of starburst macromolecules such as $\mathrm{P}=\mathrm{S}$, aromatic rings, $\mathrm{C}-\mathrm{O}$, and $\mathrm{C}=\mathrm{O}$ can be identified and characterized by XPS [144].

\subsection{Scanning Electron Microscopy}

Recently, the field of nanoscience and nanotechnology has provided a driving force in the development of various high-resolution microscopy techniques in order to learn more about nanomaterials using a beam of highly energetic electrons to probe objects on a very fine scale [145-147]. Among various electron microscopy techniques, SEM is a surface imaging method, fully capable of resolving different particle sizes, size distributions, nanomaterial shapes, and the surface morphology of the synthesized particles at the micro and nanoscales $[10,117,137,148,149]$. Using SEM, we can probe 
the morphology of particles and derive a histogram from the images by either by measuring and counting the particles manually, or by using specific software [117]. The combination of SEM with energy-dispersive X-ray spectroscopy (EDX) can be used to examine silver powder morphology and also conduct chemical composition analysis. The limitation of SEM is that it is not able to resolve the internal structure, but it can provide valuable information regarding the purity and the degree of particle aggregation. The modern high-resolution SEM is able to identify the morphology of nanoparticles below the level of $10 \mathrm{~nm}$.

\subsection{Transmission Electron Microscopy}

TEM is a valuable, frequently used, and important technique for the characterization of nanomaterials, used to obtain quantitative measures of particle and/or grain size, size distribution, and morphology $[10,109,150]$. The magnification of TEM is mainly determined by the ratio of the distance between the objective lens and the specimen and the distance between objective lens and its image plane [150]. TEM has two advantages over SEM: it can provide better spatial resolution and the capability for additional analytical measurements $[10,148,150]$. The disadvantages include a required high vacuum, thin sample section $[10,109,148]$, and the vital aspect of TEM is that sample preparation is time consuming. Therefore, sample preparation is extremely important in order to obtain the highest-quality images possible.

\subsection{Atomic Force Microscopy}

Generally, AFM is used to investigate the dispersion and aggregation of nanomaterials, in addition to their size, shape, sorption, and structure; three different scanning modes are available, including contact mode, non-contact mode, and intermittent sample contact mode [10,14,151-155]. AFM can also be used to characterize the interaction of nanomaterials with supported lipid bilayers in real time, which is not achievable with current electron microscopy (EM) techniques [113]. In addition, AFM does not require oxide-free, electrically conductive surfaces for measurement, does not cause appreciable damage to many types of native surfaces, and it can measure up to the sub-nanometer scale in aqueous fluids $[156,157]$. However, a major drawback is the overestimation of the lateral dimensions of the samples due to the size of the cantilever $[158,159]$. Therefore, we have to provide much attention to avoid erroneous measurements [160]. Furthermore, the choice of operating mode-no contact or contact-is a crucial factor in sample analysis [160].

\subsection{Localized Surface Plasmon Resonance (LSPR)}

LSPR is a coherent, collective spatial oscillation of the conduction electrons in a metallic nanoparticle, which can be directly excited by near-visible light. The localized surface plasmon resonance (LSPR) condition is defined by several factors, including the electronic properties of the nanoparticle, the size and shape of the particle, temperature, the dielectric environment, and so on. Small changes in the local dielectric environment cause the dysfunction of LSPR. The frequency of the LSPR spectral peak is very sensitive to the nanostructure environment through the local refractive index. Thereby, shifts of the LSPR frequency are widely used as a method for the detection of molecular interaction close to the surface of the nanoparticle [161-166]. In addition, the near-field enhancement has led to a very large variety of advances in many fundamental and applied areas of science, particularly for the determination of nanoparticle shapes, dimensions, and compositions. This spectroscopy method is being used to investigate fundamental properties and processes of nanoparticles in (bio)-molecular detection devices, or (bio)-imaging tools with improved single-molecule sensitivity. LSPR spectroscopy can provide thermodynamic and real-time kinetic data for binding processes. LSPR-based tools will be helpful to analyze faster and with higher sensitivity. The application of LSPR spectroscopy is mainly used for biological and chemical sensing by transducing changes in the local refractive index via a wavelength-shift measurement, due to its sensitivity, wavelength tunability, smaller sensing volumes, and lower instrumentation cost. Single-nanoparticle 
LSPR spectroscopy is an important tool for understanding the relationship between local structure and spectra. In addition, single nanoparticles can provide even higher refractive-index sensitivity than nanoparticle arrays.

\section{Properties of AgNPs}

Physical and chemical properties of AgNPs-including surface chemistry, size, size distribution, shape, particle morphology, particle composition, coating/capping, agglomeration, dissolution rate, particle reactivity in solution, efficiency of ion release, cell type, and finally type of reducing agents used for synthesis-are crucial factors for determination of cytotoxicity [15,50,167-176]. For example, using biological reducing agents such as culture supernatants of various Bacillus species, AgNPs can be synthesized in various shapes, such as spherical, rod, octagonal, hexagonal, triangle, flower-like, and so on (Figure 2). Previous studies supported the assertion that smaller size particles could cause more toxicity than larger, because they have larger surface area [176]. Shape is equally important to the determination of toxicity [177]. For example, in the biomedical field, various types of nanostructures have been used, including nanocubes, nanoplates, nanorods, spherical nanoparticles, flower-like, and so on $[175,178]$. AgNP toxicity mainly depends on the availability of chemical and or biological coatings on the nanoparticle surface [179]. AgNP surface charges could determine the toxicity effect in cells. For instance, the positive surface charge of these NPs renders them more suitable, allowing them to stay for a long time in blood stream compared to negatively-charged NPs [180], which is a major route for the administration of anticancer agents [181,182].
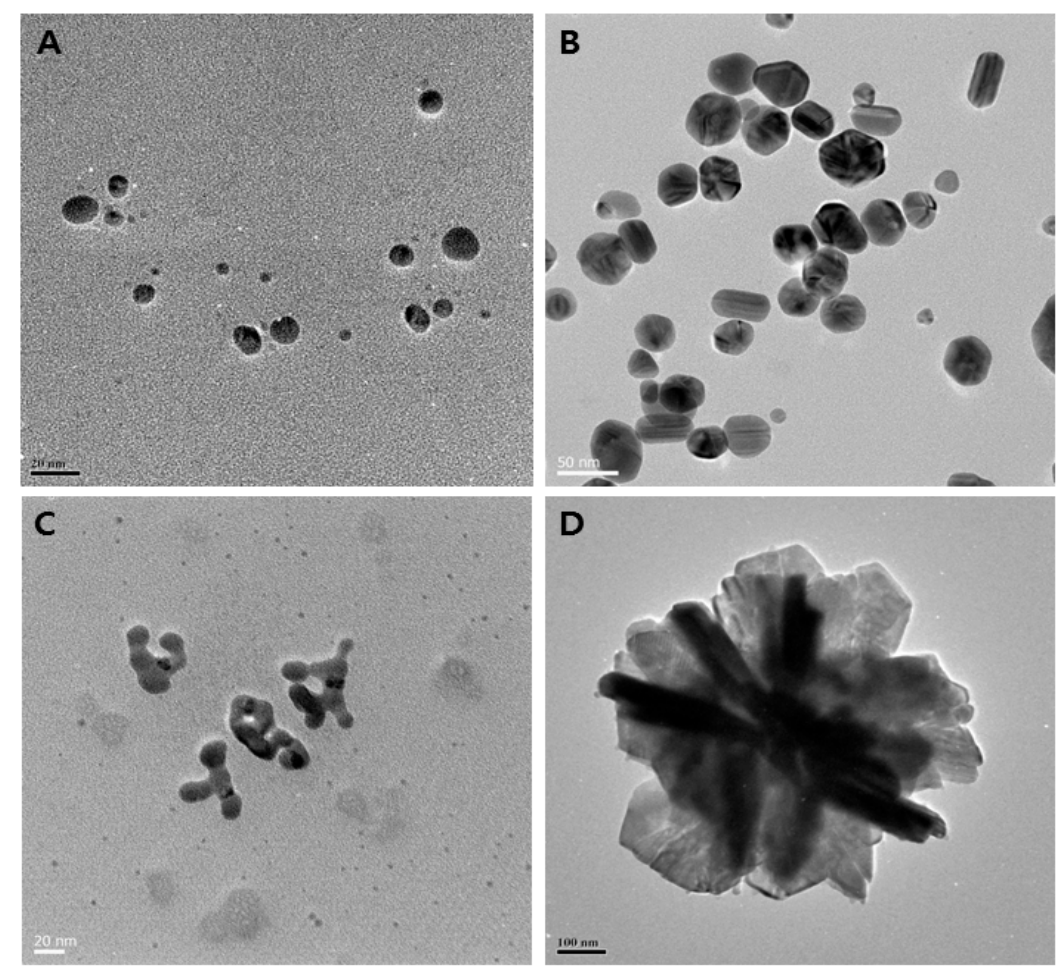

Figure 2. Biological synthesis of various shapes of AgNPs using culture supernatant of various Bacillus species. (A) Spherical; (B) mixed populations (octagonal, rod, hexagonal, and icosahedral); (C) highly branched; (D) flower-like in shape.

\section{Biological Applications of AgNPs}

Due to their unique properties, AgNPs have been used extensively in house-hold utensils, the health care industry, and in food storage, environmental, and biomedical applications. Several reviews and book chapters have been dedicated in various areas of the application of AgNPs. 
Herein, we are interested in emphasizing the applications of AgNPs in various biological and biomedical applications, such as antibacterial, antifungal, antiviral, anti-inflammatory, anti-cancer, and anti-angiogenic. Herein, we specifically addressed previously-published seminal papers and end with recent updates. A schematic diagram representing various applications of AgNPs is provided in Figure 3.

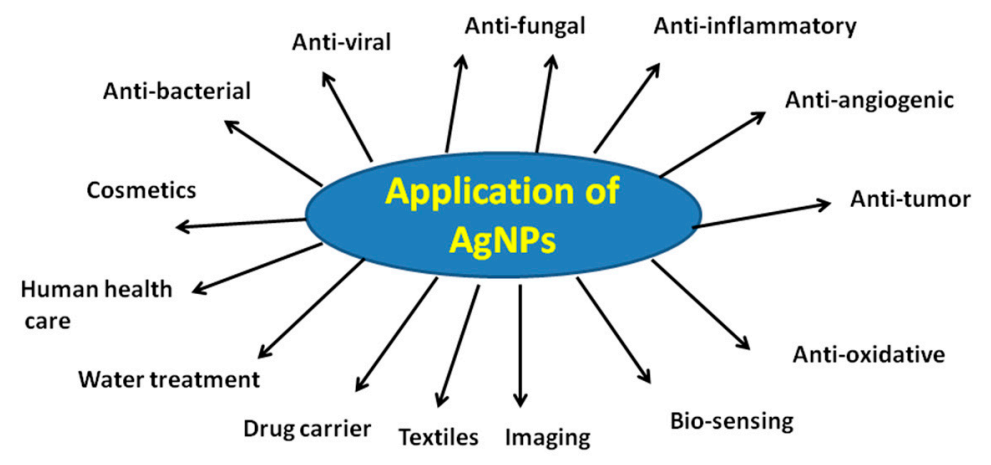

Figure 3. Various applications of AgNPs.

\subsection{Antibacterial Activity of AgNPs}

AgNPs seem to be alternative antibacterial agents to antibiotics and have the ability to overcome the bacterial resistance against antibiotics. Therefore, it is necessary to develop AgNPs as antibacterial agents. Among the several promising nanomaterials, AgNPs seem to be potential antibacterial agents due to their large surface-to-volume ratios and crystallographic surface structure. The seminal paper reported by Sondi and Salopek-Sondi [6] demonstrated the antimicrobial activity of AgNPs against Escherichia coli, in which E. coli cells treated with AgNPs showed the accumulation of AgNPs in the cell wall and the formation of "pits" in the bacterial cell walls, eventually leading to cell death. In the same E. coli strain, smaller particles with a larger surface-to-volume ratio showed a more efficient antibacterial activity than larger particles [183]. Furthermore, the antibacterial activity of AgNPs is not only size-but also shape-dependent [70]. AgNPs were synthesized by four different types of saccharides with an average size of $25 \mathrm{~nm}$, showing high antimicrobial and bactericidal activity against Gram-positive and Gram-negative bacteria, including highly multi-resistant strains such as methicillin-resistant Staphylococcus aureus. As mentioned previously, not only the size is important for determining the efficiency, but also shape, because AgNPs undergo a shape-dependent interaction with the Gram-negative organism E. coli [71]. Furthermore, a detailed study was carried out to investigate the efficiency of the antimicrobial effects of AgNPs against yeast, E. coli, and Staphylococcus aureus. The results suggest that at low concentrations of AgNPs, the complete inhibition of growth was observed in yeast and E. coli, whereas a mild effect was observed in S. aureus [184]. Biologically synthesized AgNPs from the culture supernatants of Klebsiella pneumoniae were evaluated; the efficiencies of various antibiotics, such as penicillin $\mathrm{G}$, amoxicillin, erythromycin, clindamycin, and vancomycin against Staphylococcus aureus and E. coli were increased in the presence of Ag-NPs [185]. When compared to AgNPs, hydrogel-silver nanocomposites showed excellent antibacterial activity against $E$. coli. One-pot synthesis of chitosan-Ag-nanoparticle composite was found to have higher antimicrobial activity than its components at their respective concentrations, because one-pot synthesis favors the formation of small AgNPs attached to the polymer, which can be dispersed in media of $\mathrm{pH} \leq 6.3$ [186]. Biologically produced AgNPs using culture supernatants of Staphylococcus aureus showed significant antimicrobial activity against methicillin-resistant $S$. aureus, followed by methicillin-resistant Staphylococcus epidermidis and Streptococcus pyogenes, whereas only moderate antimicrobial activity was observed against Salmonella typhi and Klebsiella pneumoniae [187]. The mechanisms of AgNP-induced cell death was observed in E. coli through the leakage of reducing sugars and proteins. Furthermore, AgNPs are able to destroy the permeability of the 
bacterial membranes via the generation of many pits and gaps, indicating that AgNPs could damage the structure of the bacterial cell membrane [2]. Silver nanocrystalline chlorhexidine (AgCHX) complex showed strong antibacterial activity against the tested Gram-positive/negative and methicillin-resistant Staphylococcus aureus (MRSA) strains. Interestingly, the minimal inhibitory concentrations (MICs) of nanocrystalline $\mathrm{Ag}$ (III)CHX were much lower than those of the ligand (CHX), $\mathrm{AgNO}_{3}$, and the gold standard, silver sulfadiazine [188].

Biofilms are not only leads to antimicrobial resistance, but are involved in the development of ocular-related infectious diseases, such as microbial keratitis [189]. Kalishwaralal and co-workers demonstrated the potential anti-biofilm activity against Pseudomonas aeruginosa and Staphylococcus epidermidis. Similarly, guava leaf extract reduced AgNPs (Gr-Ag-NPs) showed significant antibacterial activity and stability against $E$. coli compared to chemically synthesized AgNPs; the reason for this higher activity could be the adsorption of biomolecules on the surface of the Gr-Ag-NPs [190]. AgNPs synthesized by Cryphonectria sp. showed antibacterial activity against various human pathogenic bacteria, including S. aureus, E. coli, Salmonella typhi, and Candida albicans. Interestingly, these particular AgNPs exhibited higher antibacterial activity against both $S$. aureus and E. coli than against S. typhi and C. albicans. Figure 4 shows the effectiveness of dose-dependent antibacterial activity of biologically synthesized AgNPs in E. coli.

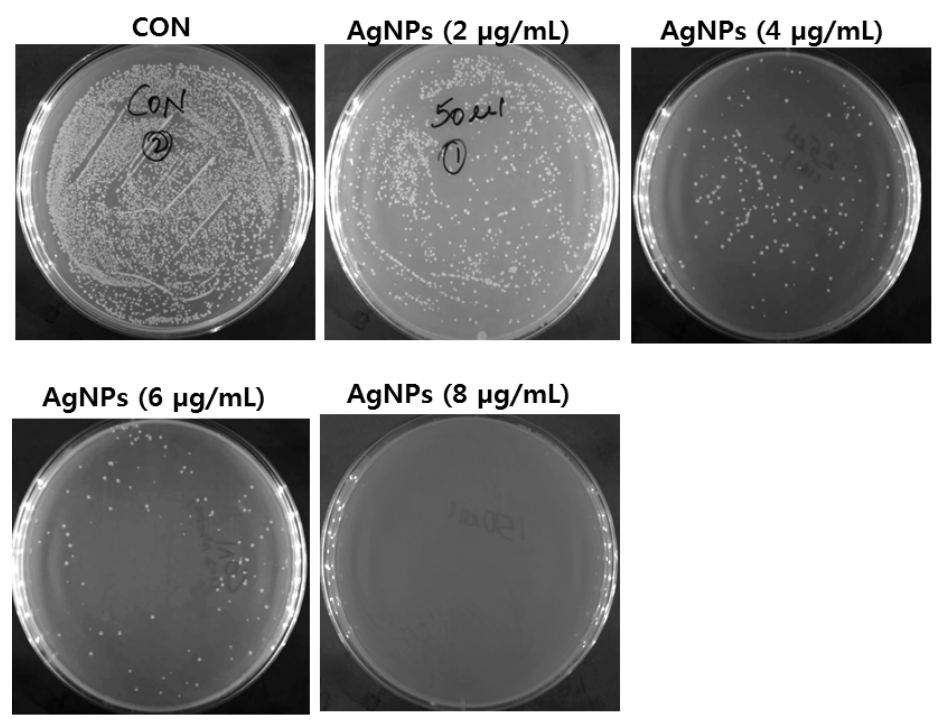

Figure 4. Dose-dependent antibacterial activity of biologically synthesized AgNPs in E. coli. CON: control.

Besinis et al. [191] compared the toxic efficiency of different nanomaterials, such as AgNPs, silver, and titanium dioxide against routine disinfectant chlorhexidine in Streptococcus mutans. Among various nanomaterials, AgNPs had the strongest antibacterial activity of the NPs tested. Agnihotri et al. [192] demonstrated that the mechanisms of AgNPs on bactericidal action using AgNPs immobilized on an amine-functionalized silica surface. They found that contact killing is the predominant bactericidal mechanism, and surface-immobilized nanoparticles show greater efficacy than colloidal AgNPs, as well as a higher concentration of silver ions in solution. The nanocomposite containing silver/polyrhodanine nanocomposite-decorated silica nanoparticles shows potential and enhanced antibacterial activity against E. coli and S. aureus, which is due to the particular combination of AgNPs and the polyrhodanine [155]. Interestingly, Khurana et al. [193] investigated the antimicrobial properties of silver based on its physical and surface properties against S. aureus, B. megaterium, $P$. vulgaris, and $S$. sonnei. The enhancement of antibacterial action was observed with particles having a hydrodynamic size of $59 \mathrm{~nm}$ compared to $83 \mathrm{~nm}$. Gurunathan et al. [68] reported that the antibacterial and anti-biofilm activity of antibiotics, AgNPs, or combinations of AgNPs 
against important pathogenic bacteria Pseudomonas aeruginosa, Shigella flexneri, Staphylococcus aureus, and Streptococcus pneumoniae. The results suggest that, the combination of both antibiotics and AgNPs showed significant antimicrobial and anti-biofilm effects at the lowest concentration of antibiotics and AgNPs compared to AgNPs or antibiotics alone. Nanocomposite spheres composed of AgNPs decorated on the polymer colloids exhibited excellent antibacterial activity [194]. Recently, nanocomposites containing graphene and AgNPs showed much interest in antibacterial activity. Graphene oxide (GO)-Ag nanocomposite showed enhanced antibacterial activity against $E$. coli and S. aureus using the conventional plate count method and disk diffusion method [195]. The GO-Ag nanocomposite exhibited an excellent antibacterial activity against methicillin-resistant S. aureus, Acinetobacter baumannii, Enterococcus faecalis, and Escherichia coli. In addition, GO-Ag nanocomposite is a promising antibacterial agent against common nosocomial bacteria, particularly antibiotic-resistant MRSA [196]. AgNPs derived from fungal extracts as reducing agents (F-AgNPs) showed enhanced antibacterial activity both in Pseudomonas aeruginosa and Staphylococcus aureus when compared to AgNPs derived from the culture supernatant of bacteria (B-AgNPs) (Figure 5). The minimum inhibitory concentration of F-AgNPs is lesser than B-AgNPs. Nano-silver interacts with peptides and bacteria and serves as nanomedicine in various bacteria, fungi, and virus-mediated diseases [197].

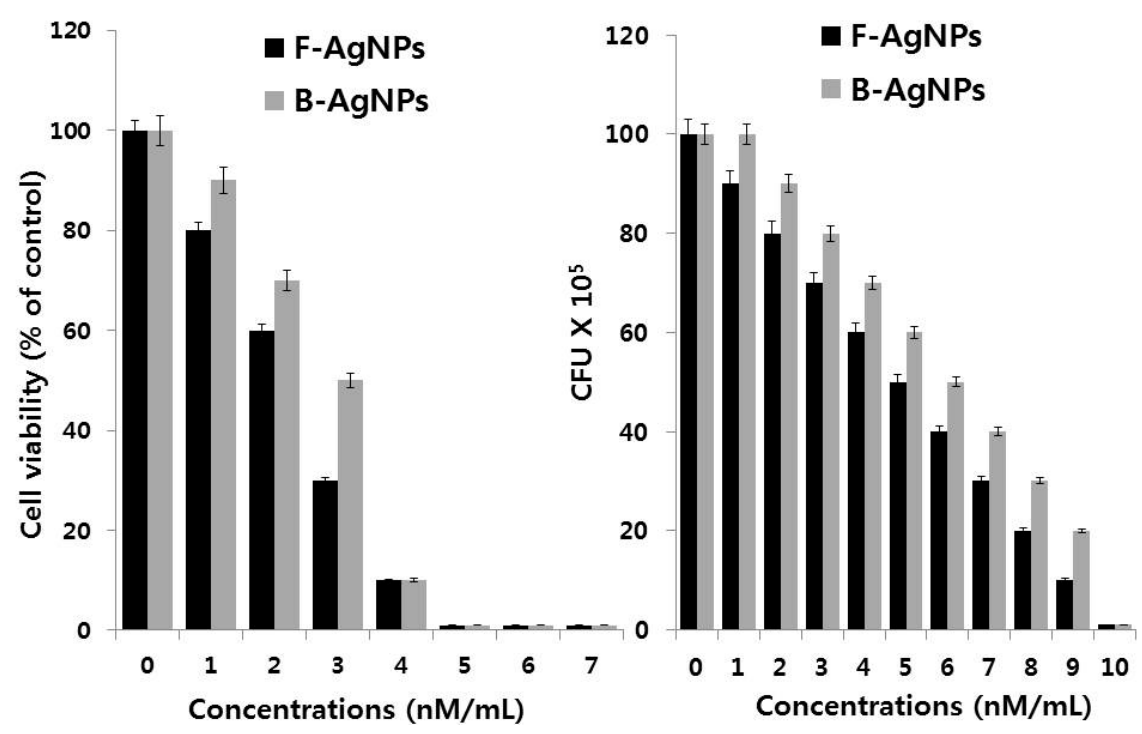

Figure 5. Differential antibacterial activity of AgNPs synthesized with Calocybe indica extracts (F-AgNPs) and the culture supernatant of Bacillus tequilensis (B-AgNPs) as reducing agents.

\subsection{Antifungal Activity of AgNPs}

Fungal infections are more frequent in patients who are immunosuppressed, and overcoming fungi-mediated diseases is a tedious process, because currently there is a limited number of available antifungal drugs [198]. Therefore, there is an inevitable and urgent need to develop antifungal agents, which should be biocompatible, non-toxic, and environmentally friendly. At this juncture, AgNPs play an important role as anti-fungal agents against various diseases caused by fungi. Nano-Ag showed potent anti-fungal activity against clinical isolates and ATCC strains of Trichophyton mentagrophytes and Candida species with concentrations of 1-7 $\mu \mathrm{g} / \mathrm{mL}$. Esteban-Tejeda et al. [199] developed an inert matrix containing AgNPs with an average size of $20 \mathrm{~nm}$ into a soda-lime glass which shows enhanced biocidal activity. Monodisperse Nano-Ag sepiolite fibers showed significant antifungal activity against Issatchenkia orientalis. AgNPs exhibited good antifungal activity against Aspergillus niger and a MIC of $25 \mu \mathrm{g} / \mathrm{mL}$ against Candida albicans [200]. Biologically-synthesized AgNPs showed enhanced antifungal activity with fluconazole against Phoma glomerata, Phoma herbarum, Fusarium semitectum, Trichoderma sp., and Candida albicans [201]. AgNPs stabilized by sodium dodecyl sulfate showed enhanced antifungal 
activity against Candida albicans compared to conventional antifungal agents [20]. The size-dependent antifungal activities of different AgNPs were performed against mature Candida albicans and Candida glabrata biofilms. Biologically synthesized AgNPs exhibited antifungal activity against several phytopathogenic fungi, including Alternaria alternata, Sclerotinia sclerotiorum, Macrophomina phaseolina, Rhizoctonia solani, Botrytis cinerea, and Curvularia lunata at the concentration of $15 \mathrm{mg}$ [202,203]. Similarly, The AgNPs synthesized by Bacillus species exhibited strong antifungal activity against the plant pathogenic fungus Fusarium oxysporum at the concentration of $8 \mu \mathrm{g} / \mathrm{mL}$ [204]. Carbon nanoscrolls (CNSs) composed of graphene oxides and AgNPs exhibited enhanced and prolonged antifungal activity against Candida albicans and Candida tropical compared to GO-AgNP nanocomposites containing graphene oxide and AgNPs [205]. The antifungal efficacy of AgNPs was evaluated in combination with nystatin (NYT) or chlorhexidine (CHX) against Candida albicans and Candida glabrata biofilms. The results from this investigation suggest that AgNPs combined with either nystatin (NYT) or chlorhexidine digluconate (CHG) showed better synergistic anti-biofilm activity; however, this activity depends on the species and drug concentrations [206].

The biologically synthesized AgNPs exhibited strong antifungal activity against Bipolaris sorokiniana by the inhibition of conidial germination [207]. Interestingly, AgNPs not only inhibit human and plant pathogenic fungi, but also indoor fungal species such as Penicillium brevicompactum, Aspergillus fumigatus, Cladosporium cladosporoides, Chaetomium globosum, Stachybotrys chartarum, and Mortierella alpine cultured on agar media [208].

\subsection{Antiviral Activity of $A g N P s$}

Viral mediated diseases are common and becoming more prominent in the world; therefore, developing anti-viral agents is essential. The mechanisms of the antiviral activity of AgNPs are an important aspect in antiviral therapy. AgNPs have unique interactions with bacteria and viruses based on certain size ranges and shapes $[70,209,210]$. The antiviral activity nano-Ag incorporated into polysulfone ultrafiltration membranes (nAg-PSf) was evaluated against MS2 bacteriophage, which shows that significant antiviral activity was a result of increased membrane hydrophilicity [21]. Lara et al. [211] showed the first mechanistic study demonstrating anti-HIV activity at an early stage of viral replication. Poly vinyl pyrrolidone (PVP)-coated AgNPs prevented the transmission of cell-associated HIV-1 and cell-free HIV-1 isolates [211]. AgNPs have demonstrated efficient inhibitory activities against human immunodeficiency virus (HIV) and hepatitis B virus (HBV) [212]. A study was attempted to investigate the antiviral action of the AgNPs; the data showed that both macrophage (M)-tropic and T-lymphocyte (T)-tropic strains of HIV-1 were highly sensitive to the AgNP-coated polyurethane condom (PUC) [213]. Although several studies have shown that AgNPs could inhibit the viability of viruses, the exact mechanism of antiviral activity is still obscure. However, the studies from Trefry and Wooley found that AgNPs caused a four- to five-log reduction in viral titer at concentrations that were not toxic to cells [214]. Interestingly, in the presence of AgNPs, virus was capable of adsorbing to cells, and this viral entry is responsible for the antiviral effects of AgNPs. Hemagglutination assay indicated that AgNPs could significantly inhibit the growth of the influenza virus in Madin-Darby canine kidney cells. The study from intranasal AgNP administration in mice significantly enhanced survival, lower lung viral titer levels, minor pathologic lesions in lung tissue, and remarkable survival advantage after infection with the H3N2 influenza virus, suggesting that AgNPs had a significant role in mice survival [215]. Biologically-synthesized AgNPs inhibited the viability in herpes simplex virus (HSV) types 1 and 2 and human parainfluenza virus type 3, based on size and zeta potential of AgNPs [216]. The treatment of Vero cells with non-cytotoxic concentrations of AgNPs significantly inhibited the replication of Peste des petits ruminants virus (PPRV). The mechanisms of viral replication are due to the interaction of AgNPs with the virion surface and the virion core [217]. Tannic acid mediated the synthesis of various sizes of AgNPs capable of reducing HSV-2 infectivity both in vitro and in vivo through direct interaction, blocked virus attachment, penetration, and further spread [218].

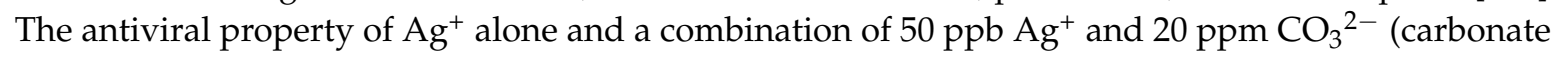


ions) was performed on bacteriophage MS2 phage. The results from this study showed that $50 \mathrm{ppb} \mathrm{Ag}^{+}$ alone was unable to affect the phage, and the combination of $50 \mathrm{ppb} \mathrm{Ag}^{+}$and $20 \mathrm{ppm} \mathrm{CO}_{3}$ was found to have an effective antiviral property within a contact time of $15 \mathrm{~min}$ [219]. Treatment with AgNPs for $24 \mathrm{~h}$ in Bean Yellow Mosaic Virus (BYMV) decreased virus concentration, percentage of infection, and disease severity [220].

\subsection{Anti-Inflammatory Activity of AgNPs}

Inflammation is an early immunological response against foreign particles by tissue, which is supported by the enhanced production of pro-inflammatory cytokines, the activation of the immune system, and the release of prostaglandins and chemotactic substances such as complement factors, interleukin-1 (IL-1), TNF- $\alpha$, and TGF- $\beta$ [221-224]. In order to overcome inflammatory action, we need to find effective anti-inflammatory agents. Among several anti-inflammatory agents, AgNPs have recently played an important role in anti-inflammatory field. AgNPs have been known to be antimicrobial, but the anti-inflammatory responses of AgNPs are still limited. Bhol and Schechter [225] reported the anti-inflammatory activity in rat. Rats treated intra-colonically with $4 \mathrm{mg} / \mathrm{kg}$ or orally with $40 \mathrm{mg} / \mathrm{kg}$ of nanocrystalline silver (NPI 32101) showed significantly reduced colonic inflammation. Mice treated with AgNPs showed rapid healing and improved cosmetic appearance, occurring in a dose-dependent manner. Furthermore, AgNPs showed significant antimicrobial properties, reduction in wound inflammation, and modulation of fibrogenic cytokines [226]. Continuing the previous study, Wong et al. [222] investigated to gain further evidence for the anti-inflammatory properties of AgNPs, in which they used both in vivo and in vitro models and found that AgNPs are able to down-regulate the quantities of inflammatory markers, suggesting that AgNPs could suppress inflammatory events in the early phases of wound healing [222]. A porcine contact dermatitis model showed that treatment with nanosilver significantly increases apoptosis in the inflammatory cells and decreased the levels of pro-inflammatory cytokines [227]. Biologically-synthesized AgNPs can inhibit the production of cytokines induced by UV-B irradiation in HaCaT cells, and also reduces the edema and cytokine levels in the paw tissues [228].

\subsection{Anti-Angiogenic Activity of AgNPs}

Pathological angiogenesis is a symbol of cancer and various ischemic and inflammatory diseases [229]. There are several research groups interested in discovering novel pro- and anti-angiogenic molecules to overcome angiogenic-related diseases. Although there are several synthetic molecules having anti-angiogenic properties, the discovery of a series of natural pro- and anti-angiogenic factors suggests that this may provide a more physiological approach to treat both classes of angiogenesis-dependent diseases in the near future [230]. Recently, several studies provided supporting evidence using both in vitro and in vivo models showing that AgNPs have both anti-angiogenic and anti-cancer properties. Herein, we wish to summarize the important contribution in cancer and other angiogenic related diseases.

Kalishwaralal et al. [231] demonstrated the anti-angiogenic property of biologically synthesized AgNPs using bovine retinal endothelial cells (BRECs) as a model system, in which they found the inhibition of proliferation and migration in BRECs after $24 \mathrm{~h}$ of treatment with AgNPs at $500 \mathrm{nM}$ concentration. The mechanisms of inhibition of vascular endothelial growth factor (VEGF) induced angiogenic process by the activation of caspase-3 and DNA fragmentation, and AgNPs inhibited the VEGF-induced PI3K/Akt pathway in BRECs [232]. Followed by this study, Gurunathan et al. [23] provided evidence for the anti-angiogenic property of AgNPs by using pigment epithelium derived factor (PEDF) as a bench mark, which is known as a potent anti-angiogenic agent. Using BRECs as an in vitro model system, they found that AgNPs inhibited VEGF-induced angiogenic assays. Furthermore, they demonstrated that AgNPs could block the formation of new blood microvessels by the inactivation of PI3K/Akt. The same group also demonstrated the anticancer property of AgNPs using various cytotoxicity assays in Dalton's lymphoma ascites (DLA) cells, and a tumor 
mouse model showed significantly increased survival time in the presence of AgNPs [24]. AgNPs reduced with diaminopyridinyl (DAP)-derivatized heparin (HP) polysaccharides (DAPHP) inhibited basic fibroblast growth factor (FGF-2)-induced angiogenesis compared to glucose conjugation [232]. Kim et al. [233] developed an anti-angiogenic Flt1 peptide conjugated to tetra- $N$-butyl ammonium modified hyaluronate (HA-TBA), and it was used to encapsulate genistein. Using human umbilical vein endothelial cells (HUVECs) as in vitro model system, they found that genistein/Flt1 peptide-HA micelle inhibited the proliferation of HUVECs, and the same reagents could drastically reduce corneal neovascularization in silver nitrate-cauterized corneas of Sprague Dawley (SD) rats. $\mathrm{Ag}_{2} \mathrm{~S}$ quantum dots (QDs) used as nanoprobes to monitor lymphatic drainage and vascular networks. $\mathrm{Ag}_{2} \mathrm{~S}$-based nanoprobes showed long circulation time and high stability. In addition, they were able to track angiogenesis mediated by a tiny tumor (2-3 mm in diameter) in vivo [5]. Recently, Achillea biebersteinii flowers extract-mediated synthesis of AgNPs containing a concentration of $200 \mu \mathrm{g} / \mathrm{mL}$ showed a $50 \%$ reduction in newly-formed vessels [234]. Figure 6 shows the inhibitory effect of AgNPs on VEGF induced angiogenic activity in bovine retinal endothelial cells (BRECs) and human breast cancer cells MDA-MB 231.

A

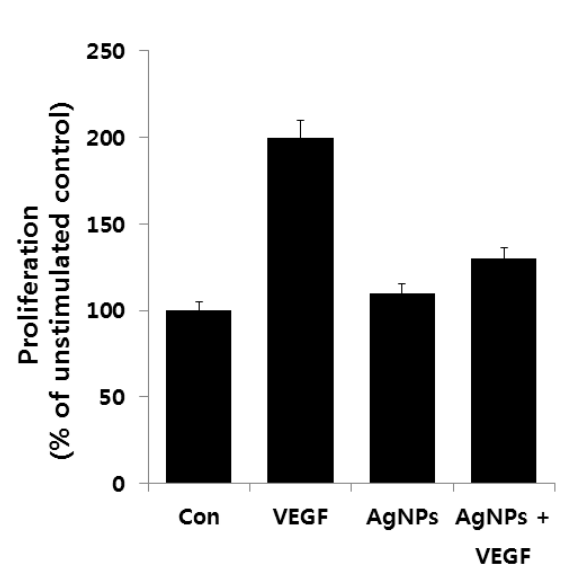

B

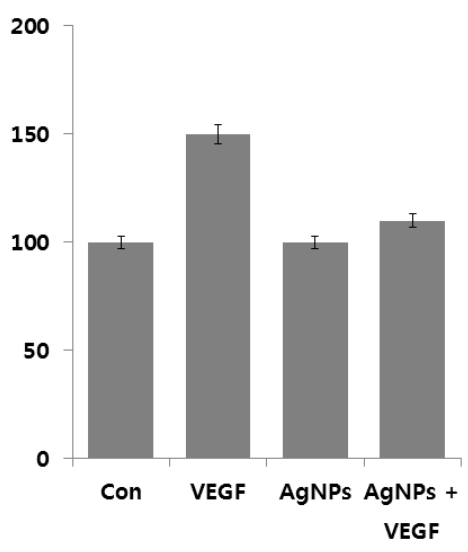

Figure 6. Effect of AgNPs on vascular endothelial growth factor (VEGF)-induced proliferation of (A) bovine retinal endothelial cells (BRECs); and (B) human breast cancer cells MDA-MB 231. Cells were treated with VEGF with or without AgNPs for $24 \mathrm{~h}$. Cell proliferation was determined by trypan blue exclusion assay.

\subsection{Anticancer Activity of $A g N P s$}

In our lifetime, 1 in 3 people has the possibility to develop cancer [235]. Although many chemotherapeutic agents are currently being used on different types of cancers, the side effects are enormous, and particularly, administrations of chemotherapeutic agents by intravenous infusion are a tedious process [235]. Therefore, it is indispensable to develop technologies to avoid systemic side effects. At this juncture, many researchers are interested in developing nanomaterials as an alternative tool to create formulations that can target tumor cells specifically. Several research laboratories have used various cell lines to address the possibility of finding a new molecule to battle cancer. Here we summarized the work from various laboratories reporting anticancer activity using both in vitro and in vivo model systems. Gopinath et al. [236] investigated the molecular mechanism of AgNPs and found that programmed cell death was concentration-dependent under conditions. Further, they observed a synergistic effect on apoptosis using uracil phosphoribosyltransferase (UPRT)-expressing cells and non-UPRT-expressing cells in the presence of fluorouracil (5-FU). In these experimental conditions, they observed that AgNPs not only induce apoptosis but also sensitize cancer cells. The anticancer property of starch-coated AgNPs was studied in normal human lung fibroblast cells (IMR-90) and human glioblastoma cells (U251). AgNPs induced alterations in cell morphology, decreased cell viability 
and metabolic activity, and increased oxidative stress leading to mitochondrial damage and increased production of reactive oxygen species (ROS), ending with DNA damage. Among these two cell types, U251 cells showed more sensitivity than IMR-90 [237]. The same group also demonstrated that the cellular uptake of AgNPs occurred mainly through endocytosis. AgNP-treated cells exhibited various abnormalities, including upregulation of metallothionein, downregulation of major actin binding protein, filamin, and mitotic arrest [237]. The morphology analysis of cancer cells suggests that biologically synthesized AgNPs could induce cell death very significantly. Jun et al. [238] elegantly prepared multifunctional silver-embedded magnetic nanoparticles, in which the first type consist of silver-embedded magnetic NPs with a magnetic core of average size $18 \mathrm{~nm}$ and another type consist of a thick silica shell with silver having an average size of $16 \mathrm{~nm}$; the resulting silica-encapsulated magnetic NPs (M-SERS dots) produce strong surface-enhanced Raman scattering (SERS) signals and have magnetic properties, and these two significant properties were used for targeting breast-cancer cells (SKBR3) and floating leukemia cells (SP2/O).

The antineoplastic activities of protein-conjugated silver sulfide nano-crystals are size dependent in human hepatocellular carcinoma Bel-7402 and C6 glioma cells [239]. Instead of giving direct treatment of AgNPs into the cells, some researchers developed chitosan as a carrier molecule for the delivery of silver to the cancer cells. For example, Sanpui et al. [240] demonstrated that chitosan-based nanocarrier (NC) delivery of AgNPs induces apoptosis at very low concentrations. They then examined cytotoxic efficiency using a battery of biochemical assays. They found an increased level of intracellular ROSin HT 29 cells. Lower concentrations of nanocarrier with AgNPs showed better inhibitory results than AgNPs alone. Boca et al. [241] reported that chitosan-coated silver nanotriangles (Chit-AgNTs) show an increased cell mortality rate. In addition, human embryonic cells (HEK) were able to take up Chit-AgNTs efficiently, and the cytotoxic effect of various sizes of AgNPs was significant in acute myeloid leukemia (AML) cells [242]. Recently, the anticancer property of bacterial (B-AgNPs) and fungal extract-produced AgNPs (F-AgNPs) was demonstrated in human breast cancer MDA-MB-231 cells. Both biologically produced AgNPs exhibited significant cytotoxicity $[62,243]$. Among these two AgNPs, fungal extract-derived AgNPs had a stronger effect than B-AgNPs, which is due to the type of reducing agents used for the synthesis of AgNPs. Similarly, AgNPs derived from Escherichia fergusoni showed dose-dependent cytotoxicity against MCF-7 cells [62]. Plant extract-mediated synthesis of AgNPs showed more pronounced toxic effect in human lung carcinoma cells (A549) than non-cancer cells like human lung cells, indicating that AgNPs could target cell-specific toxicity, which could be the lower level of $\mathrm{pH}$ in the cancer cells [63]. Targeted delivery is an essential process for the treatment of cancer. To address this issue, Locatelli et al. [244] developed multifunctional nanocomposites containing polymeric nanoparticles (PNPs) containing alisertib (Ali) and AgNPs. PNPs conjugated with a chlorotoxin (Ali@PNPs-Cltx) showed a nonlinear dose-effect relationship, whereas the toxicity of Ag/Ali@PNPs-Cltx remained stable. Biologically synthesized AgNPs showed significant toxicity in MCF7 and T47D cancer cells by higher endocytic activity than MCF10-A normal breast cell line [245]. Banti and Hadjikakou explained the detailed account of anti-proliferative and anti-tumor activity of silver(I) compounds [246]. Biologically synthesized AgNPs capable of altering cell morphology of cancer cells (Figure 7), which is an early indicator for apoptosis. Apoptosis can be determined by structural alterations in cells by transmitted light microscopy. 


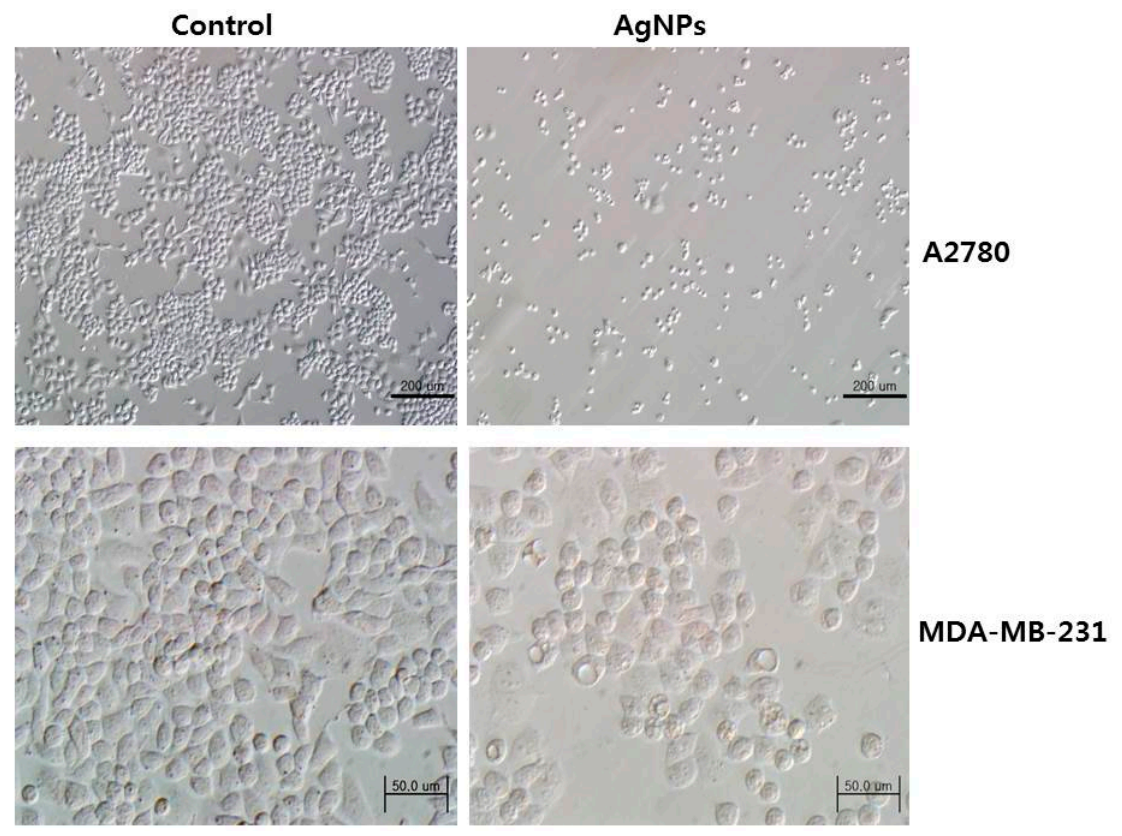

Figure 7. Anticancer activity of biologically synthesized AgNPs using Bacillus species in human ovarian cancer and human breast cancer cells.

\subsection{Diagnostic, Biosensor, and Gene Therapy Applications of AgNPs}

The advancement in medical technologies is increasing. There is much interest in using nanoparticles to improve or replace today's therapies. Nanoparticles have advantages over today's therapies, because they can be engineered to have certain properties or to behave in a certain way. Recent developments in nanotechnology are the use of nanoparticles in the development of new and effective medical diagnostics and treatments. The ability of AgNPs in cellular imaging in vivo could be very useful for studying inflammation, tumors, immune response, and the effects of stem cell therapy, in which contrast agents were conjugated or encapsulated to nanoparticles through surface modification and bioconjugation of the nanoparticles. Silver plays an important role in imaging systems due its stronger and sharper plasmon resonance. AgNPs, due to their smaller size, are mainly used in diagnostics, therapy, as well as combined therapy and diagnostic approaches by increasing the acoustic reflectivity, ultimately leading to an increase in brightness and the creation of a clearer image $[247,248]$. Nanosilver has been intensively used in several applications, including diagnosis and treatment of cancer and as drug carriers [249-251]. Nanosilver was used in combination with vanadium oxide in battery cell components to improve the battery performance in next-generation active implantable medical devices [250]. Recently, silver has been used to develop silver-based biosensors for the clinical detection of serum p53 in head and neck squamous cell carcinoma [252]. In addition, it has been explored for the location of cancer cells, and can absorb light and selectively destroy targeted cancer cells through photothermal therapy [253].

\section{Mechanism of the Anti-Cancer Activity of AgNPs}

The next interesting aspect of silver is to find out the mechanism of AgNP-induced apoptosis in cancer cells. In this context, AshaRani et al. [254] investigated the cellular and molecular mechanisms of nanoparticle-induced effects using normal human lung cells IMR-90 and human brain cancer cells U251. They found that AgNPs were capable of adsorbing cytosolic proteins on their surface that may influence the function of intracellular factors, and that they can regulate gene expression and pro-inflammatory cytokines. Foldbjerg et al. [255] addressed the interesting aspect of cellular transcriptome analysis upon exposure of human lung epithelial cell line A549 using microarray analysis. The results from this study exhibited that AgNPs could alter the regulation of more than 1000 genes. 
Among several genes, metallothionein, heat shock protein, and histone families were significant [255]. Recently, autophagy-induced cell death has been another identified mechanism for the anti-cancer activity of AgNPs. Autophagy induced by nanoparticles is a critical cellular degradation process, and elevated autophagy could promote cell death [256]. Our recent findings show that AgNPs are capable of inducing autophagy through the accumulation of autophagolysosmes in human ovarian cancer cells (Figure 8). Therefore, autophagy can have a dual function; at lower levels, it can enhance the cell survival, and at elevated levels, it can cause cell death. Therefore, the use of autophagy inhibitors or autophagy protein-5 (ATG5)—small interfering RNAs (siRNA) enhanced AgNPs induced cell death in cancer cells.

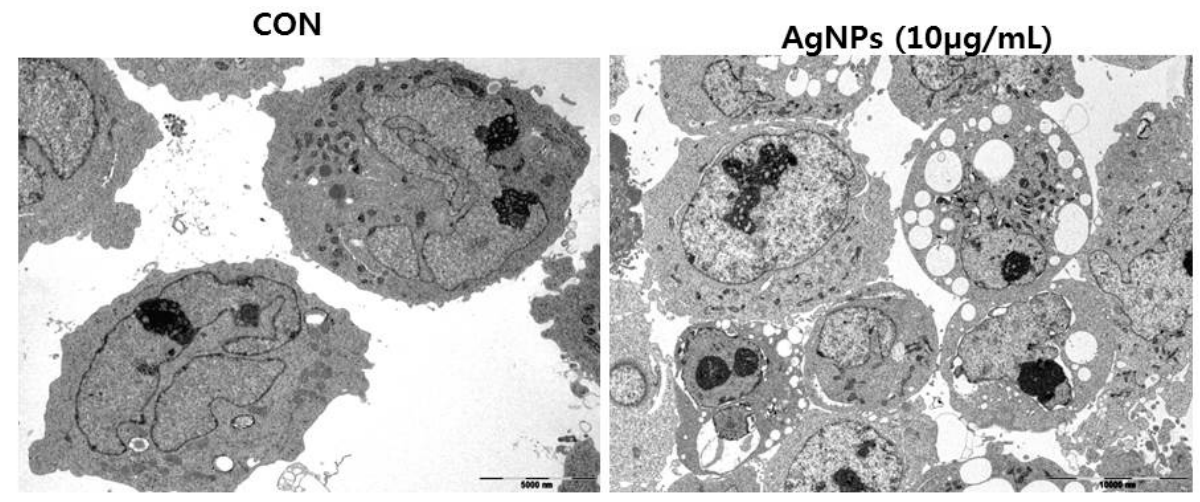

Figure 8. Biologically synthesized AgNPs using Bacillus species induce accumulation of autophagolysosomes in human ovarian cancer cells.

The antitumor activity of AgNPs was significantly enhanced in B16 mouse melanoma cells by the inhibition of autophagy using wortmanin [256]. One of the most important mechanisms of the toxicity of AgNPs is that excessive levels of intracellular ion concentration increases the production of ROS, which is produced by cellular oxygen metabolism $[15,68]$. On other hand, uncontrolled ROS production can lead to serious cellular injuries [15], such as DNA damage and mitochondria-involved apoptotic cell death [1,257-259]. Recently, De Matteis et al. [260] proposed that endocytosed AgNPs are degraded in the lysosomes, and the release of $\mathrm{Ag}^{+}$ions in the cytosol induces cell damages. Hatipoglu et al. [261] revealed that the cytotoxicity and genotoxicity of AgNPs depends on reaction times for the preparation of AgNPs. The conclusion drawn from this study suggests that AgNP seeds were the major source of toxicity. Gurunathan et al. [1] reported that cytotoxicity of AgNPs in human breast cancer cells MDA-MB-231 via the activation of p53, p-Erk1/2, and caspase-3 signaling, and the downregulation of Bcl-2. Importantly, AgNP-mediated apoptosis was a p53-dependent pathway. On the other hand, Zuberek et al. [262] demonstrated that AgNPs not only induced oxidative stress, but also indicated the influence of energy supply from glucose availability in the media. They showed evidence by growing HepG2 cells in two different media with high $(25 \mathrm{mM})$ or low $(5.5 \mathrm{mM})$ glucose content in the presence of $20 \mathrm{~nm}$ AgNPs. In this assay, they observed that AgNPs induced the dose-dependent generation of $\mathrm{H}_{2} \mathrm{O}_{2}$. The study suggests that lower levels of glucose are responsible for defense mechanisms. All of these studies suggest that AgNPs can induce cell death through various processes, including ROS generation, enhanced leakage of lactate dehydrogenase, upregulation of apoptosis and autophagy genes, endoplasmic reticulum stress, mitochondrial dysfunction, activation of caspases, and DNA damage.

\section{Therapeutic Approach for Cancer Treatment Using AgNPs}

The application of AgNPs in cancer is divided into diagnostic and therapeutic purposes. Several laboratories have addressed the enhancement of the therapeutic usage of AgNPs as nanocarriers for targeted delivery, chemotherapeutic agents, and as enhancers for radiation and photodynamic therapy. 
Here we summarized the possible therapeutic approaches for cancer using AgNPs in cancer cell lines or animal models. For instance, Lim et al. [263] synthesized plasmonic magnetic nanoparticles to enhance MRI contrast consisting of multiple components of various nanoparticles in a single platform containing silver monolayer- gold-coated magnetic nanoparticles. These coated materials showed highly efficient killing of SKBr3 cells within 3 min of near-infrared laser at the relatively low exposure of $12.7 \mathrm{~W} / \mathrm{cm}$ at $808 \mathrm{~nm}$. To address the efficiency of photothermal therapy, Huang et al. [264] designed an aptamer-based nanostructure which combines the high absorption efficiency of Au-Ag nanorods showing excellent hyperthermia efficiency and selectivity. The combination of AgNPs with ligands strongly influences the toxicity and cellular uptake into the cells.

Recently, photo-based nanomedicine has gained much importance for cancer treatment among several approaches [265]. Khlebtsov et al. [266] developed multifunctional NPs which significantly induced cell death in HeLa cervical cancer cells. Wang et al. [267] developed folic acid (FA)-coated AgNPs with an average size of $23 \pm 2 \mathrm{~nm}$ showing excellent receptor-mediated cellular uptake; with this compound (FA-AgNPs), they conjugated the chemotherapeutic drug doxorubicin (DOX) by electrostatic bonding. DOX was released efficiently, and cell death was observed after $8 \mathrm{~h}$. They concluded that AgNPs can be used as nanocarriers for desired drugs for cancer treatment. To increase intracellular uptake and cytotoxicity in lymphoma cells, Fang et al. [268] designed self-assembled polymer-doxorubicin conjugates such as NP-Im/DOX, NP-Ag/DOX, and NP-Dm/DOX (Nanoparticles (NP), guanidinium group (Ag), an imidazole group (Im), and a tertiary amine group (Dm), doxorubicin (Dox)) using three different cationic side chains with an average of $80 \mathrm{~nm}$ for the efficient delivery of nanocarrier. Locatelli et al. [269] developed a nanocarrier by using a simple method, in which lipophilic AgNPs entrapped into PEG-based polymeric nanoparticles containing chlorotoxin. The interesting aspect using this nanocarrier showed enhanced cellular uptake and cytotoxic effect.

Recently, nanomaterials have been used for diagnosis, treatment, and prevention of cancer using photo-based therapeutic approaches [270]. The nanostructures are more capable of destroying the cancer cells than non-cancer cells at low irradiation power density [271]. In this context, Wu et al. [271] developed sensitive and specific detection aptamer-based Ag-Au shell-core nanostructure-photothermal therapy in which the nanostructures were able to target the cells with high affinity and specificity. The intra-tumoral administration of AgNPs in combination with a single dose of ionizing radiation enhanced therapeutic efficiency in C6 glioma-bearing rats [272]. Nanoparticles consisting of a silver nanoshell with a carbon core composite were significantly cytotoxic to cells in the presence of phototherapy and radiotherapy [273]. Combination of AgNPs-chitosan-para-aminothiophenol (pATP)-folic acid showed significant stability and targeted uptake in NIH:OVCAR-3 human ovarian cancer cell line. The efficient therapeutic approach was achieved by targeted cancer cell treatment with these composites [274]. Recently, Mukherjee et al. [275] used AgNPs as cancer theranostic agents; they prepared AgNPs from Olax scandens leaf extract and prepared AgNPs showing anticancer activity against various types of cancer cells, including A549, B16, and MCF7. Furthermore, they observed a bright red fluorescence signal from AgNPs, which can be exploited for localized drug delivery into the cancer cells. Considering the literature, AgNPs are not only used as drug delivery devices but they also serve as drugs; therefore, they are used for therapeutics [276]. AgNPs are well known antibacterial agents, and they also enhance the tumor-killing effects of anticancer drugs [276]. The combination of chemotherapeutic agents with nanoparticles is a developing effective approach for the eradication of cancer, in which they are using lower doses of drugs to reduce cytotoxic effects and increase the efficacy [277]. For example, the combination of Platinol (cisplatin) and Navelbine (vinorelbine) showed better efficiency in non-small cell lung cancer [278]. Combination of CPX-351 in a liposomal NP with cytarabine and daunorubicin showed better efficacy in the treatment of acute myeloid leukemia [279]. Similarly, the combination of salinomycin (Sal) with AgNPs derived from Typha angustifolia plant extracts showed a synergistic cytotoxic effect in human ovarian cancer cells (Figure 9). 
Con

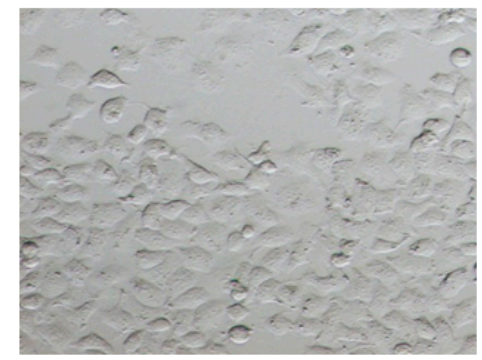

AgNPs

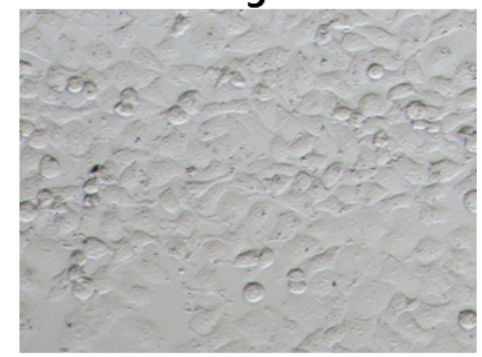

Sal

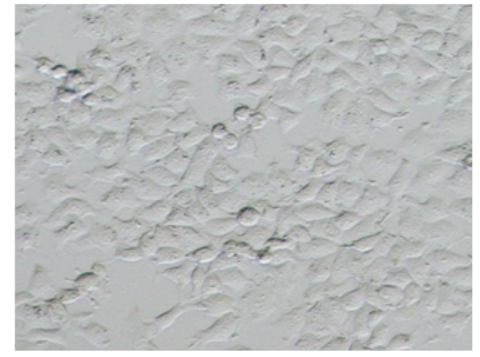

Sal + AgNPs

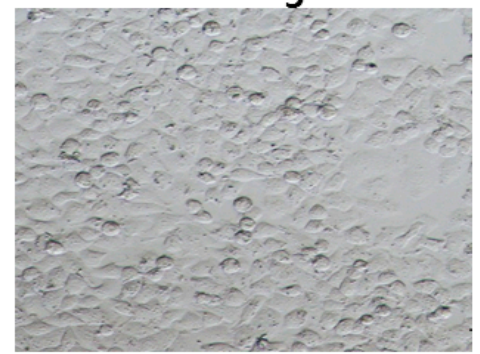

Figure 9. Morphological changes of the human ovarian cancer cell line A2780 after treatment with Salinimycin (Sal), AgNPs, and Sal plus AgNPs. A2780 cells were treated with Sal $(3 \mu \mathrm{M})$, AgNPs $(3 \mu \mathrm{g} / \mathrm{mL})$, and Sal plus AgNPs $(3 \mu \mathrm{M}$ plus $3 \mu \mathrm{g} / \mathrm{mL})$ for $24 \mathrm{~h}$, and the morphological changes of cells were observed under an inverted microscope $(200 \times)$. The combination of Sal and AgNP induced significant morphological changes.

Altogether, published literatures suggest that the AgNPs is a suitable promising agent to inhibit the growth of cancer cells via various mechanistic approaches. The hypothetical mechanism is shown in Figure 10.

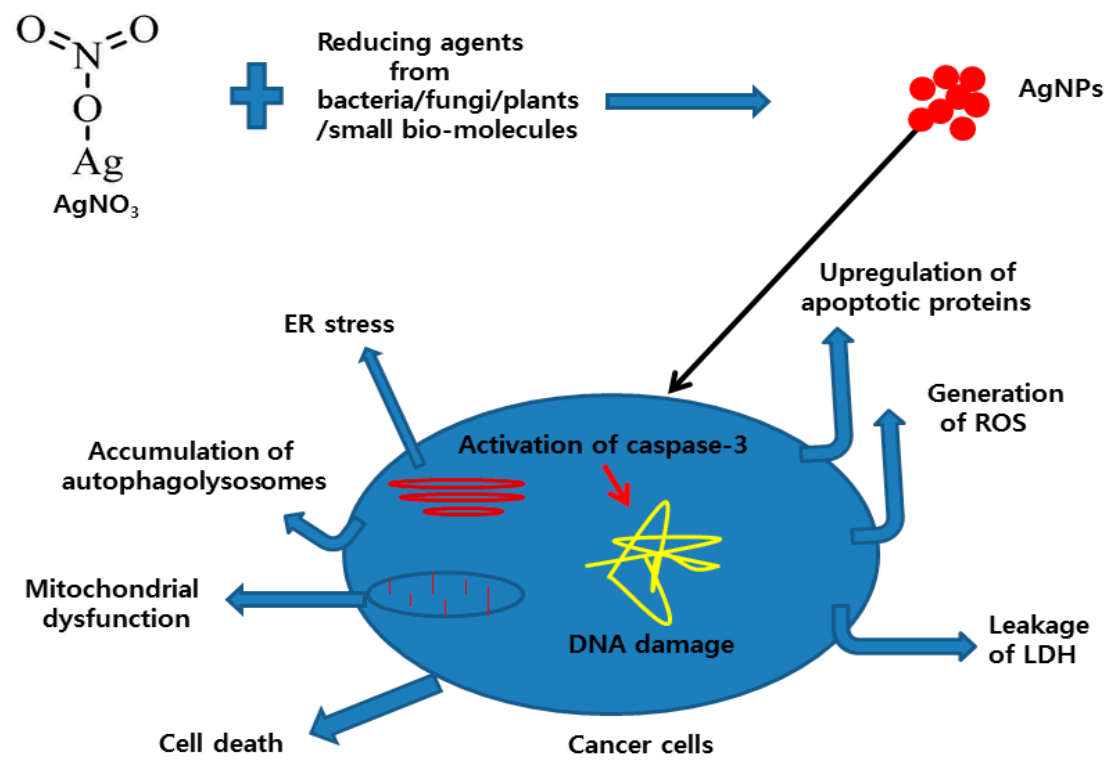

Figure 10. The possible mechanisms of AgNP-induced cytotoxicity in cancer cell lines. Endoplasmic reticulum stress(ER), lactate dehydrogenase $(\mathrm{LDH})$, reactive oxygen species (ROS).

\section{Challenges for Cancer Therapy Using AgNPs}

Nanomedicine is as one of the fast developing and promising strategies to combat cancer using metallic nanoparticles. Current treatment for cancer, such as chemo- and radiation therapy, has 
limitations due to unexpected drug-associated side effects, lack of specificity of low drug concentrations at the tumor target site, and the development of chemoresistance $[280,281]$. Nanoparticle-mediated therapy is the best, most suitable, and alternative therapeutic strategy in cancer therapy. Nanoparticles (NPs) have the ability to target through passive or active targeting of particular diseased cells or tumor tissues by the encapsulation of therapeutic agents with nanoparticles, and they have been used as drug delivery systems [282]. Although many nanoparticle-mediated strategies have been developed, heterogeneity of the tumor and its stroma is a significant challenge for nanotechnologists and clinicians to come up with specific formulations to precisely target specific cancer cells. To achieve higher specificity, reduction in toxicity, biocompatibility, safety, better efficacy, and to overcome the limitations of conventional chemotherapy, using new nanoparticles in single platform-based strategies is another challenge in cancer therapy. However, there is a need to address the challenges and limitations of using nanoparticles for cancer therapy; these include physiological barriers, limited carrying capacity, enhanced permeability and retention effect (EPR), variability of nanoparticles, and regulatory and manufacturing issues [282].

\section{Conclusions and Future Perspectives}

This review comprehensively addressed synthesis, characterization, and bio-applications of silver nanoparticles, with special emphasis on anticancer activity and its mechanisms and also therapeutic approaches for cancer using AgNPs. Recently, both academic and industrial research has explored the possibility of using AgNPs as a next-generation anticancer therapeutic agent, due to the conventional side effects of chemo- and radiation therapy. Although AgNPs play an important role in clinical research, several factors need to be considered, including the source of raw materials, the method of production, stability, bio-distribution, controlled release, accumulation, cell-specific targeting, and finally toxicological issues to human beings. The development of AgNPs as anti-angiogenic molecules is one of the most interesting approaches for cancer treatment and other angiogenesis-related diseases; it can overcome poor delivery and the problem of drug resistance. Further, it could provide a new avenue for other angiogenic diseases, such as atherosclerosis, rheumatoid arthritis, diabetic retinopathy, psoriasis, endometriosis, and adiposity.

In addition, the potential use of AgNPs for cancer diagnosis and treatment is immense; to address this issue, a variety of modalities have been developed. Although various methods are available, the synergistic effects of AgNPs and antibiotics on antibacterial agents or multiple therapeutic agents on anti-cancer activity/tumor reduction are still obscure. Therefore, more studies are required to explain the synergistic effect of the two different cytotoxic agents at a single time point. These kinds of studies could provide understanding, mechanisms, and efficiency of the synergistic effect of two different agents or multiple agents; thus, they would help to develop a novel system bearing multiple components with synergistic effects for the treatment of various types of cancer. Although AgNPs have been focused on therapeutic purposes, further research is inevitable in animal models to confirm the mechanisms and to gain a comprehensive picture of biocompatibility vs. toxicity of AgNPs. Finally, if we succeed in all these studies, it would help the researchers of the nanoscience and nanotechnology community to develop safer, biocompatible, efficient cancer or anti-angiogenic agents containing AgNPs. Eventually, to ensure the biosafety of the use of AgNPs in humans, studies dealing with biocompatibility of AgNPs and their interaction with cells and tissues are inevitable. Finally, the great concern is that the developing nanotechnology-based therapy should be better than available technologies, and it should overcome the limitations of existing treatment techniques. Finally, it has to provide a safe, reliable, and viable treatment of diseases with high accuracy in a patient-friendly manner.

Acknowledgments: This paper was supported by the KU-Research Professor Program of Konkuk University. This work is also supported by the Science and Technology Research Program from the Department of Education of Hubei Province in China (D20151701). Although we are the authors of this review, we would never have been able to complete it without the great many people who have contributed to the field of nanoparticles research 
particularly silver nanoparticles. We owe our gratitude to all those researchers who have made this review possible. We wish to thank all the investigators who have contributed to the field of synthesis, characterization, biomedical application and therapeutic approaches of silver nanoparticles. We have cited as many references as permitted, and apologize to the authors of those publications that we have not cited due to limitation of references. We apologize to other authors who have worked on the several aspects of AgNPs, but whom we have unintentionally overlooked.

Author Contributions: Sangiliyandi Gurunathan came up with the idea and participated in writing of the manuscript. Xi-Feng Zhang performed all literature surveys. Wei shen and Zhi-Guo Liu analyzed the interpretation of literature. All authors read and approved the final manuscript.

Conflicts of Interest: The authors declare no conflict of interest.

\section{References}

1. Gurunathan, S.; Park, J.H.; Han, J.W.; Kim, J.H. Comparative assessment of the apoptotic potential of silver nanoparticles synthesized by Bacillus tequilensis and Calocybe indica in MDA-MB-231 human breast cancer cells: Targeting p53 for anticancer therapy. Int. J. Nanomed. 2015, 10, 4203-4222. [CrossRef] [PubMed]

2. Li, W.R.; Xie, X.B.; Shi, Q.S.; Zeng, H.Y.; Ou-Yang, Y.S.; Chen, Y.B. Antibacterial activity and mechanism of silver nanoparticles on Escherichia coli. Appl. Microbiol. Biotechnol. 2010, 8, 1115-1122. [CrossRef] [PubMed]

3. Mukherjee, P.; Ahmad, A.; Mandal, D.; Senapati, S.; Sainkar, S.R.; Khan, M.I.; Renu, P.; Ajaykumar, P.V.; Alam, M.; Kumar, R.; et al. Fungus-mediated synthesis of silver nanoparticles and their immobilization in the mycelial matrix: A novel biological approach to nanoparticle synthesis. Nano Lett. 2001, 1, 515-519. [CrossRef]

4. Chernousova, S.; Epple, M. Silver as antibacterial agent: Ion, nanoparticle, and metal. Angew. Chem. Int. Ed. 2013, 52, 1636-1653. [CrossRef] [PubMed]

5. Li, C.Y.; Zhang, Y.J.; Wang, M.; Zhang, Y.; Chen, G.; Li, L.; Wu, D.; Wang, Q. In vivo real-time visualization of tissue blood flow and angiogenesis using $\mathrm{Ag}_{2} \mathrm{~S}$ quantum dots in the NIR-II window. Biomaterials 2014, 35, 393-400. [CrossRef] [PubMed]

6. Sondi, I.; Salopek-Sondi, B. Silver nanoparticles as antimicrobial agent: A case study on E. coli as a model for Gram-negative bacteria. J. Colloid Interface Sci. 2004, 275, 177-182. [CrossRef] [PubMed]

7. Li, L.; Hu, J.; Yang, W.; Alivisatos, A.P. Band gap variation of size- and shape-controlled colloidal CdSe quantum rods. Nano Lett. 2001, 1, 349-351. [CrossRef]

8. Sharma, V.K.; Yngard, R.A.; Lin, Y. Silver nanoparticles: Green synthesis and their antimicrobial activities. Adv. Colloid Interface 2009, 145, 83-96. [CrossRef] [PubMed]

9. Gurunathan, S.; Kalishwaralal, K.; Vaidyanathan, R.; Venkataraman, D.; Pandian, S.R.; Muniyandi, J.; Hariharan, N.; Eom, S.H. Biosynthesis, purification and characterization of silver nanoparticles using Escherichia coli. Colloids Surf. B Biointerfaces 2009, 74, 328-335. [CrossRef] [PubMed]

10. Lin, P.C.; Lin, S.; Wang, P.C.; Sridhar, R. Techniques for physicochemical characterization of nanomaterials. Biotechnol. Adv. 2014, 32, 711-726. [CrossRef] [PubMed]

11. Pleus, R. Nanotechnologies-Guidance on Physicochemical Characterization of Engineered Nanoscale Materials for Toxicologic Assessment; ISO: Geneva, Switzerland, 2012.

12. Murdock, R.C.; Braydich-Stolle, L.; Schrand, A.M.; Schlager, J.J.; Hussain, S.M. Characterization of nanomaterial dispersion in solution prior to in vitro exposure using dynamic light scattering technique. Toxicol. Sci. 2008, 101, 239-253. [CrossRef] [PubMed]

13. Gurunathan, S.; Han, J.W.; Kim, E.S.; Park, J.H.; Kim, J.H. Reduction of graphene oxide by resveratrol: A novel and simple biological method for the synthesis of an effective anticancer nanotherapeutic molecule. Int. J. Nanomed. 2015, 10, 2951-2969. [CrossRef] [PubMed]

14. Sapsford, K.E.; Tyner, K.M.; Dair, B.J.; Deschamps, J.R.; Medintz, I.L. Analyzing nanomaterial bioconjugates: A review of current and emerging purification and characterization techniques. Anal. Chem. 2011, 83, 4453-4488. [CrossRef] [PubMed]

15. Carlson, C.; Hussain, S.M.; Schrand, A.M.; Braydich-Stolle, L.K.; Hess, K.L.; Jones, R.L.; Schlager, J.J. Unique cellular interaction of silver nanoparticles: Size-dependent generation of reactive oxygen species. J. Phys. Chem. B 2008, 112, 13608-13619. [CrossRef] [PubMed]

16. Jo, D.H.; Kim, J.H.; Lee, T.G.; Kim, J.H. Size, surface charge, and shape determine therapeutic effects of nanoparticles on brain and retinal diseases. Nanomedicine 2015, 11, 1603-1611. [CrossRef] [PubMed] 
17. Staquicini, F.I.; Ozawa, M.G.; Moya, C.A.; Driessen, W.H.; Barbu, E.M.; Nishimori, H.; Soghomonyan, S.; Flores, L.G.; Liang, X.; Paolillo, V.; et al. Systemic combinatorial peptide selection yields a non-canonical iron-mimicry mechanism for targeting tumors in a mouse model of human glioblastoma. J. Clin. Investig. 2011, 121, 161-173. [CrossRef] [PubMed]

18. Duan, X.P.; Li, Y.P. Physicochemical characteristics of nanoparticles affect circulation, biodistribution, cellular internalization, and trafficking. Small 2013, 9, 1521-1532. [CrossRef] [PubMed]

19. Albanese, A.; Tang, P.S.; Chan, W.C. The effect of nanoparticle size, shape, and surface chemistry on biological systems. Annu. Rev. Biomed. Eng. 2012, 14, 1-16. [CrossRef] [PubMed]

20. Panáček, A.; Kolář, M.; Večeřová, R.; Prucek, R.; Soukupová, J.; Kryštof, V.; Hamal, P.; Zbořil, R.; Kvítek, L. Antifungal activity of silver nanoparticles against Candida spp. Biomaterials 2009, 30, 6333-6340. [CrossRef] [PubMed]

21. Zodrow, K.; Brunet, L.; Mahendra, S.; Li, D.; Zhang, A.; Li, Q.; Alvarez, P.J. Polysulfone ultrafiltration membranes impregnated with silver nanoparticles show improved biofouling resistance and virus removal. Water Res. 2009, 43, 715-723. [CrossRef] [PubMed]

22. Wong, K.K.; Cheung, S.O.; Huang, L.; Niu, J.; Tao, C.; Ho, C.M.; Che, C.M.; Tam, P.K. Further evidence of the anti-inflammatory effects of silver nanoparticles. ChemMedChem 2009, 4, 1129-1135. [CrossRef] [PubMed]

23. Gurunathan, S.; Lee, K.J.; Kalishwaralal, K.; Sheikpranbabu, S.; Vaidyanathan, R.; Eom, S.H. Antiangiogenic properties of silver nanoparticles. Biomaterials 2009, 30, 6341-6350. [CrossRef] [PubMed]

24. Sriram, M.I.; Kanth, S.B.M.; Kalishwaralal, K.; Gurunathan, S. Antitumor activity of silver nanoparticles in Dalton's lymphoma ascites tumor model. Int. J. Nanomed. 2010, 5, 753-762.

25. American Cancer Society. Cancer Facts \& Figures 2015; American Cancer Society: Atlanta, GA, USA, 2015.

26. Gurav, A.S.; Kodas, T.T.; Wang, L.M.; Kauppinen, E.I.; Joutsensaari, J. Generation of nanometer-size fullerene particles via vapor condensation. Chem. Phys. Lett. 1994, 218, 304-308. [CrossRef]

27. Kruis, F.E.; Fissan, H.; Rellinghaus, B. Sintering and evaporation characteristics of gas-phase synthesis of size-selected PbS nanoparticles. Mater. Sci. Eng. B 2000, 69, 329-334. [CrossRef]

28. Magnusson, M.H.; Deppert, K.; Malm, J.O.; Bovin, J.O.; Samuelson, L. Size-selected gold nanoparticles by aerosol technology. Nanostruct. Mater. 1999, 12, 45-48. [CrossRef]

29. Schmidt-Ott, A. New approaches to in situ characterization of ultrafine agglomerates. J. Aerosol Sci. 1988, 19, 553-563. [CrossRef]

30. Tien, D.C.; Liao, C.Y.; Huang, J.C.; Tseng, K.H.; Lung, J.K.; Tsung, T.T.; Kao, W.S.; Tsai, T.H.; Cheng, T.W.; $\mathrm{Yu}$, B.S.; et al. Novel technique for preparing a nano-silver water suspension by the arc-discharge method. Rev. Adv. Mater. Sci. 2008, 18, 750-756.

31. Pluym, T.; Powell, Q.; Gurav, A.; Ward, T.; Kodas, T.; Glicksman, H. Solid silver particle production by spray pyrolysis. J. Aerosol Sci. 1993, 24, 383-392. [CrossRef]

32. Elsupikhe, R.F.; Shameli, K.; Ahmad, M.B.; Ibrahim, N.A.; Zainudin, N. Green sonochemical synthesis of silver nanoparticles at varying concentrations of K-carrageenan. Nanoscale Res. Lett. 2015, 10, 302. [CrossRef] [PubMed]

33. Shameli, K.; Ahmad, M.B.; Yunus, W.M.Z.W.; Ibrahim, N.A.; Gharayebi, Y.; Sedaghat, S. Synthesis of silver/montmorillonite nanocomposites using $\gamma$-irradiation. Int. J. Nanomed. 2010, 5, 1067-1077. [CrossRef] [PubMed]

34. Shameli, K.; Ahmad, M.B.; Yunus, W.M.; Rustaiyan, A.; Ibrahim, N.A.; Zargar, M.; Abdollahi, Y. Green synthesis of silver/montmorillonite/chitosan bionanocomposites using the UV irradiation method and evaluation of antibacterial activity. Int. J. Nanomed. 2010, 5, 875-887. [CrossRef] [PubMed]

35. Tsuji, M.; Hashimoto, M.; Nishizawa, Y.; Kubokawa, M.; Tsuji, T. Microwave-assisted synthesis of metallic nanostructures in solution. Chem. Eur. J. 2005, 11, 440-452. [CrossRef] [PubMed]

36. Abou El-Nour, K.M.; Eftaiha, A.; Al-Warthan, A.; Ammar, R.A. Synthesis and applications of silver nanoparticles. Arab. J. Chem. 2010, 3, 135-140. [CrossRef]

37. Tao, A.; Sinsermsuksakul, P.; Yang, P. Polyhedral silver nanocrystals with distinct scattering signatures. Angew. Chem. Int. Ed. 2006, 45, 4597-4601. [CrossRef] [PubMed]

38. Wiley, B.; Sun, Y.; Mayers, B.; Xia, Y. Shape-controlled synthesis of metal nanostructures: The case of silver. Chemistry 2005, 11, 454-463. [CrossRef] [PubMed] 
39. Deepak, V.; Umamaheshwaran, P.S.; Guhan, K.; Nanthini, R.A.; Krithiga, B.; Jaithoon, N.M.; Gurunathan, S. Synthesis of gold and silver nanoparticles using purified URAK. Colloid Surface B 2011, 86, 353-358. [CrossRef] [PubMed]

40. Amulyavichus, A.; Daugvila, A.; Davidonis, R.; Sipavichus, C. Study of chemical composition of nanostructural materials prepared by laser cutting of metals. Fiz. Met. Metalloved. 1998, 85, 111-117.

41. Mallick, K.; Witcomb, M.J.; Scurrell, M.S. Polymer stabilized silver nanoparticles: A photochemical synthesis route. J. Mater. Sci. 2004, 39, 4459-4463. [CrossRef]

42. Malik, M.A.; O'Brien, P.; Revaprasadu, N. A simple route to the synthesis of core/shell nanoparticles of chalcogenides. Chem. Mater. 2002, 14, 2004-2010. [CrossRef]

43. Sergeev, B.M.; Kasaikin, V.A.; Litmanovich, E.A.; Sergeev, G.B.; Prusov, A.N. Cryochemical synthesis and properties of silver nanoparticle dispersions stabilised by poly(2-dimethylaminoethyl methacrylate). Mendeleev Commun. 1999, 4, 130-132. [CrossRef]

44. Mafuné, F.; Kohno, J.Y.; Takeda, Y.; Kondow, T.; Sawabe, H. Formation and size control of silver nanoparticles by laser ablation in aqueous solution. J. Phys. Chem. B 2000, 104, 9111-9117. [CrossRef]

45. Hulteen, J.C.; Treichel, D.A.; Smith, M.T.; Duval, M.L.; Jensen, T.R.; van Duyne, R.P. Nanosphere lithography: Size-tunable silver nanoparticle and surface cluster arrays. J. Phys. Chem. B 1999, 103, 3854-3863. [CrossRef]

46. Zhu, J.J.; Liao, X.H.; Zhao, X.N.; Chen, H.Y. Preparation of silver nanorods by electrochemical methods. Mater. Lett. 2001, 49, 91-95. [CrossRef]

47. Abid, J.P.; Wark, A.W.; Brevet, P.F.; Girault, H.H. Preparation of silver nanoparticles in solution from a silver salt by laser irradiation. Chem. Commun. 2002, 7, 792-793. [CrossRef]

48. Talebi, J.; Halladj, R.; Askari, S. Sonochemical synthesis of silver nanoparticles in Y-zeolite substrate. J. Mater. Sci. 2010, 45, 3318-3324. [CrossRef]

49. Hosseinpour-Mashkani, S.M.; Ramezani, M. Silver and silver oxide nanoparticles: Synthesis and characterization by thermal decomposition. Mater. Lett. 2014, 130, 259-262. [CrossRef]

50. Zhang, Q.; Li, N.; Goebl, J.; Lu, Z.D.; Yin, Y.D. A systematic study of the synthesis of silver nanoplates: Is citrate a "Magic" Reagent? J. Am. Chem. Soc. 2011, 133, 18931-18939. [CrossRef] [PubMed]

51. Ganaie, S.U.; Abbasi, T.; Abbasi, S.A. Green synthesis of silver nanoparticles using an otherwise worthless weed mimosa (Mimosa pudica): Feasibility and process development toward shape/size control. Part. Sci. Technol. 2015, 33, 638-644. [CrossRef]

52. Gurunathan, S.; Han, J.; Park, J.H.; Kim, J.H. A green chemistry approach for synthesizing biocompatible gold nanoparticles. Nanoscale Res. Lett. 2014, 9, 248. [CrossRef] [PubMed]

53. Gurunathan, S.; Han, J.W.; Kim, J.H. Green chemistry approach for the synthesis of biocompatible graphene. Int. J. Nanomed. 2013, 8, 2719-2732. [CrossRef] [PubMed]

54. Gurunathan, S.; Han, J.W.; Park, J.H.; Kim, E.; Choi, Y.J.; Kwon, D.N.; Kim, J.H. Reduced graphene oxide-silver nanoparticle nanocomposite: A potential anticancer nanotherapy. Int. J. Nanomed. 2015, 10, 6257-6276. [CrossRef] [PubMed]

55. Kalimuthu, K.; Babu, R.S.; Venkataraman, D.; Bilal, M.; Gurunathan, S. Biosynthesis of silver nanocrystals by Bacillus licheniformis. Colloid Surface B 2008, 65, 150-153. [CrossRef] [PubMed]

56. Kalishwaralal, K.; Deepak, V.; Ramkumarpandian, S.; Nellaiah, H.; Sangiliyandi, G. Extracellular biosynthesis of silver nanoparticles by the culture supernatant of Bacillus licheniformis. Mater. Lett. 2008, 62, 4411-4413. [CrossRef]

57. Mullen, M.D.; Wolf, D.C.; Ferris, F.G.; Beveridge, T.J.; Flemming, C.A.; Bailey, G.W. Bacterial sorption of heavy metals. Appl. Environ. Microbiol. 1989, 55, 3143-3149. [PubMed]

58. Klaus, T.; Joerger, R.; Olsson, E.; Granqvist, C.G. Silver-based crystalline nanoparticles, microbially fabricated. Proc. Natl. Acad. Sci. USA 1999, 96, 13611-13614. [CrossRef] [PubMed]

59. Nair, B.; Pradeep, T. Coalescence of nanoclusters and formation of submicron crystallites assisted by Lactobacillus strains. Cryst. Growth Des. 2002, 2, 293-298. [CrossRef]

60. Kalishwaralal, K.; Deepak, V.; Ram Kumar Pandian, S.; Kottaisamy, M.; BarathmaniKanth, S.; Kartikeyan, B.; Gurunathan, S. Biosynthesis of silver and gold nanoparticles using Brevibacterium casei. Colloids Surf. B Biointerfaces 2010, 77, 257-262. [CrossRef] [PubMed]

61. Shankar, S.S.; Ahmad, A.; Sastry, M. Geranium leaf assisted biosynthesis of silver nanoparticles. Biotechnol. Prog. 2003, 19, 1627-1631. [CrossRef] [PubMed] 
62. Gurunathan, S.; Han, J.W.; Dayem, A.A.; Dayem, A.A.; Eppakayala, V.; Park, J.H.; Cho, S.G.; Lee, K.J.; Kim, J.H. Green synthesis of anisotropic silver nanoparticles and its potential cytotoxicity in human breast cancer cells (MCF-7). J. Ind. Eng. Chem. 2013, 19, 1600-1605. [CrossRef]

63. Gurunathan, S.; Jeong, J.K.; Han, J.W.; Zhang, X.F.; Park, J.H.; Kim, J.H. Multidimensional effects of biologically synthesized silver nanoparticles in Helicobacter pylori, Helicobacter felis, and human lung (L132) and lung carcinoma A549 cells. Nanoscale Res. Lett. 2015, 10, 1-17. [CrossRef] [PubMed]

64. Gurunathan, S. Biologically synthesized silver nanoparticles enhances antibiotic activity against Gram-negative bacteria. J. Ind. Eng. Chem. 2015, 29, 217-226. [CrossRef]

65. Leung, T.C.; Wong, C.K.; Xie, Y. Green synthesis of silver nanoparticles using biopolymers, carboxymethylated-curdlan and fucoidan. Mater. Chem. Phys. 2010, 121, 402-405. [CrossRef]

66. Kumar, B.; Smita, K.; Cumbal, L.; Debut, A.; Pathak, R.N. Sonochemical synthesis of silver nanoparticles using starch: A comparison. Bioinorg. Chem. Appl. 2014, 2014, 784268. [CrossRef] [PubMed]

67. Shankar, S.; Rhim, J.W. Amino acid mediated synthesis of silver nanoparticles and preparation of antimicrobial agar/silver nanoparticles composite films. Carbohydr. Polym. 2015, 130, 353-363. [CrossRef] [PubMed]

68. Gurunathan, S.; Han, J.W.; Kwon, D.N.; Kim, J.H. Enhanced antibacterial and anti-biofilm activities of silver nanoparticles against Gram-negative and Gram-positive bacteria. Nanoscale Res. Lett. 2014, 9, 373. [CrossRef] [PubMed]

69. Thakkar, K.N.; Mhatre, S.S.; Parikh, R.Y. Biological synthesis of metallic nanoparticles. Nanomedicine 2010, 6, 257-262. [CrossRef] [PubMed]

70. Morones, J.R.; Elechiguerra, J.L.; Camacho, A.; Holt, K.; Kouri, J.B.; Ramírez, J.T.; Yacaman, M.J. The bactericidal effect of silver nanoparticles. Nanotechnology 2005, 16, 2346-2353. [CrossRef] [PubMed]

71. Pal, S.; Tak, Y.K.; Song, J.M. Does the antibacterial activity of silver nanoparticles depend on the shape of the nanoparticle? A study of the gram-negative bacterium Escherichia coli. Appl. Environ. Microbiol. 2007, 73, 1712-1720. [CrossRef] [PubMed]

72. Pyatenko, A.; Yamaguchi, M.; Suzuki, M. Synthesis of spherical silver nanoparticles with controllable sizes in aqueous solutions. J. Phys. Chem. C 2007, 111, 7910-7917. [CrossRef]

73. Khodashenas, B.; Ghorbani, H.R. Synthesis of silver nanoparticles with different shapes. Arab. J. Chem. 2015. [CrossRef]

74. Sastry, M.; Patil, V.; Sainkar, S.R. Electrostatically controlled diffusion of carboxylic acid derivatized silver colloidal particles in thermally evaporated fatty amine films. J. Phys. Chem. B 1998, 102, 1404-1410. [CrossRef]

75. UV/VIS/IR Spectroscopy Analysis of Nanoparticles, 2012. Available online: http://50.87.149.212/sites/ default/files/nanoComposix\%20Guidelines\%20for\%20UV-vis\%20Analysis.pdf (accessed on 5 March 2016).

76. Huang, X.H.; Jain, P.K.; El-Sayed, I.H.; El-Sayed, M.A. Gold nanoparticles: Interesting optical properties and recent applications in cancer diagnostic and therapy. Nanomed. Lond. 2007, 2, 681-693. [CrossRef] [PubMed]

77. Leung, A.B.; Suh, K.I.; Ansari, R.R. Particle-size and velocity measurements in flowing conditions using dynamic light scattering. Appl. Opt. 2006, 45, 2186-2190. [CrossRef] [PubMed]

78. Tomaszewska, E.; Soliwoda, K.; Kadziola, K.; Celichowski, G.; Cichomski, M.; Szmaja, W.; Grobelny, J. Detection limits of DLS and UV-vis spectroscopy in characterization of polydisperse nanoparticles colloids. J. Nanomater. 2013, 2013, 313081. [CrossRef]

79. Das, R.; Nath, S.S.; Chakdar, D.; Gope, G.; Bhattacharjee, R. Preparation of silver nanoparticles and their characterization. J. Nanotechnol. 2009, 5, 1-6.

80. Kreibig, U.; Vollmer, M. Optical Properties of Metal Clusters; Springer: Berlin, Germany, 1995.

81. Link, S.; Ei-Sayed, M.A. Optical properties and ultrafast dynamics of metallic nanocrystals. Annu. Rev. Phys. Chem. 2003, 54, 331-366. [CrossRef] [PubMed]

82. Noginov, M.A.; Zhu, G.; Bahoura, M.; Adegoke, J.; Small, C.; Ritzo, B.A.; Draciiev, V.P.; Siialaev, V.M. The effect of gain and absorption on surface plasmons in metal nanoparticles. Appl. Phys. B 2007, 86, 455-460. [CrossRef]

83. Nath, S.S.; Gope, D.G. Synthesis of CdS and ZnS quantum dots and their applications in Electronics. Nano Trends 2007, 2, 20-28.

84. Taleb, A.; Petit, C.; Pileni, M.P. Optical properties of self-assembled 2D and 3D superlattices of silver nanoparticles. J. Phys. Chem. B 1998, 102, 2214-2220. [CrossRef] 
85. He, R.; Qian, X.F.; Yin, J.; Zhu, Z.K. Preparation of polychrome silver nanoparticles in different solvents. J. Mater. Chem. 2002, 12, 3783-3786. [CrossRef]

86. Henglein, A. Physicochemical properties of small metal particles in solution: "Microelectrode" reactions, chemisorption, composite metal particles, and the atom-to-metal transition. J. Phys. Chem. 1993, 97, 5457-5471. [CrossRef]

87. Sastry, M.; Mayya, K.S.; Bandyopadhyay, K. pH Dependent changes in the optical properties of carboxylic acid derivatized silver colloidal particles. Colloids Surf. A Physicochem. Eng. Asp. 1997, 127, 221-228. [CrossRef]

88. Waseda, Y.; Matsubara, E.; Shinoda, K. X-ray Diffraction Crystallography: Introduction, Examples and Solved Problems; Springer Verlag: Berlin, Germany, 2011.

89. Ivanisevic, I. physical stability studies of miscible amorphous solid dispersions. J. Pharm. Sci. 2010, 99, 4005-4012. [CrossRef] [PubMed]

90. Cabral, M.; Pedrosa, F.; Margarido, F.; Nogueira, C.A. End-of-life Zn-MnO 2 batteries: Electrode materials characterization. Environ. Technol. 2013, 34, 1283-1295. [CrossRef] [PubMed]

91. Dey, A.; Mukhopadhyay, A.K.; Gangadharan, S.; Sinha, M.K.; Basu, D. Characterization of microplasma sprayed hydroxyapatite coating. J. Therm. Spray Technol. 2009, 18, 578-592. [CrossRef]

92. Ananias, D.; Paz, F.A.; Carlos, L.D.; Rocha, J. Chiral microporous rare-earth silico-germanates: Synthesis, structure and photoluminescence properties. Microporous Mesoporous Mater. 2013, 166, 50-58. [CrossRef]

93. Singh, D.K.; Pandey, D.K.; Yadav, R.R.; Singh, D. A study of ZnO nanoparticles and ZnO-EG nanofluid. J. Exp. Nanosci. 2013, 8, 567-577. [CrossRef]

94. Robin, T.M. Introduction to powder diffraction and its application to nanoscale and heterogeneous materials. Nanotechnol. Undergrad. Educ. 2009, 1010, 75-86.

95. Zawrah, M.F.; Zayed, H.A.; Essawy, R.A.; Nassar, A.H.; Taha, M.A. Preparation by mechanical alloying, characterization and sintering of $\mathrm{Cu}-20$ wt. \% $\mathrm{Al}_{2} \mathrm{O}_{3}$ nanocomposites. Mater. Des. 2013, 46, 485-490. [CrossRef]

96. Yazdian, N.; Karimzadeh, F.; Enayati, M.H. In-situ fabrication of $\mathrm{Al}_{3} \mathrm{~V} / \mathrm{Al}_{2} \mathrm{O}_{3}$ nanocomposite through mechanochemical synthesis and evaluation of its mechanism. Adv. Powder Technol. 2013, 24, 106-112. [CrossRef]

97. Wu, H.; He, L.; Gao, M.M.; Gao, S.Y.; Liao, X.P.; Shi, B. One-step in situ assembly of size-controlled silver nanoparticles on polyphenol-grafted collagen fiber with enhanced antibacterial properties. New J. Chem. 2011, 35, 2902-2909. [CrossRef]

98. Vaia, R.A.; Liu, W. X-ray powder diffraction of polymer/layered silicate nanocomposites: Model and practice. J. Polym. Sci. Part B Polym. Phys. 2002, 40, 1590-1600. [CrossRef]

99. Ray, S.S.; Okamoto, M. Polymer/layered silicate nanocomposites: A review from preparation to processing. Prog. Polym. Sci. 2003, 28, 1539-1641.

100. Pavlidou, S.; Papaspyrides, C.D. A review on polymer-layered silicate nanocomposites. Prog. Polym. Sci. 2008, 33, 1119-1198. [CrossRef]

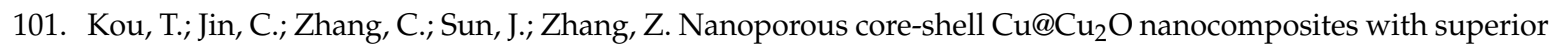
photocatalytic properties towards the degradation of methyl orange. Rsc. Adv. 2012, 2, 12636-12643. [CrossRef]

102. Khan, A.; Asiri, A.M.; Rub, M.A.; Azum, N.; Khan, A.A.P.; Khan, S.B.; Rahman, M.M.; Khan, I. Synthesis, characterization of silver nanoparticle embedded polyaniline tungstophosphate-nanocomposite cation exchanger and its application for heavy metal selective membrane. Compos. Part B Eng. 2013, 45, 1486-1492. [CrossRef]

103. Dolatmoradi, A.; Raygan, S.; Abdizadeh, H. Mechanochemical synthesis of W-Cu nanocomposites via in-situ co-reduction of the oxides. Powder Technol. 2013, 233, 208-214. [CrossRef]

104. Aghili, S.E.; Enayati, M.H.; Karimzadeh, F. In-situ synthesis of alumina reinforced ( $\mathrm{Fe}, \mathrm{Cr})_{3} \mathrm{Al}$ intermetallic matrix nanocomposite. Mater. Manuf. Process. 2012, 27, 1348-1353. [CrossRef]

105. Cantor, C.R. Techniques for the Study of Biological Structure and Function; Schimmel, P.R., Ed.; W.H. Freeman: San Francisco, CA, USA, 1980.

106. Das, R.; Ali, E.; Hamid, S.B. Current applications of X-ray powder diffraction-A review. Rev. Adv. Mater. Sci. 2014, 38, 95-109. 
107. Caminade, A.M.; Laurent, R.; Majoral, J.P. Characterization of dendrimers. Adv. Drug Deliv. Rev. 2005, 57, 2130-2146. [CrossRef] [PubMed]

108. Zanchet, D.; Hall, B.D.; Ugarte, D. X-ray characterization of nanoparticles. In Characterization of Nanophase Materials; Wiley-VCH Verlag GmbH: Weinheim, Germany, 2001; pp. 13-36.

109. Joshi, M.; Bhattacharyya, A. Characterization techniques for nanotechnology applications in textiles. Indian J. Fiber Text. Res. 2008, 33, 304-317.

110. Cao, G. Nanostructures and Nanomaterials: Synthesis, Properties, and Applications; World Scientific Publishing Inc.: Hackensack, NJ, USA, 2011.

111. Chapman, H.N.; Fromme, P.; Barty, A.; White, T.A.; Kirian, R.A.; Aquila, A.; Hunter, M.S.; Schulz, J.; DePonte, D.P.; Weierstall, U.; et al. Femtosecond X-ray protein nanocrystallography. Nature 2011, 470, $73-77$. [CrossRef] [PubMed]

112. Inagaki, S.; Ghirlando, R.; Grisshammer, R. Biophysical characterization of membrane proteins in nanodiscs. Methods 2013, 59, 287-300. [CrossRef] [PubMed]

113. Stephan, T.S.; Scott, E.M.; Anil, K.P.; Marina, A.D. Preclinical characterization of engineered nanoparticles intended for cancer therapeutics. In Nanotechnology for Cancer Therapy; Amiji, M.M., Ed.; CRC Press: Boca Raton, FL, USA, 2006; pp. 105-137.

114. Jans, H.; Liu, X.; Austin, L.; Maes, G.; Huo, Q. Dynamic light scattering as a powerful tool for gold nanoparticle bioconjugation and biomolecular binding studies. Anal. Chem. 2009, 81, 9425-9432. [CrossRef] [PubMed]

115. Khlebtsov, B.N.; Khlebtsov, N.G. On the measurement of gold nanoparticle sizes by the dynamic light scattering method. Colloid J. 2011, 73, 118-127. [CrossRef]

116. Zanetti-Ramos, B.G.; Fritzen-Garcia, M.B.; de Oliveira, C.S.; Pasa, A.A.; Soldi, V.; Borsali, R.; Creczynski-Pasa, T. Dynamic light scattering and atomic force microscopy techniques for size determination of polyurethane nanoparticles. Mater. Sci. Eng. C 2009, 29, 638-640. [CrossRef]

117. Fissan, H.; Ristig, S.; Kaminski, H.; Asbach, C.; Epple, M. Comparison of different characterization methods for nanoparticle dispersions before and after aerosolization. Anal. Methods 2014, 6, 7324-7334. [CrossRef]

118. Berne, B.J.; Pecora, R. Dynamic Light Scattering: With Applications to Chemistry, Biology, and Physics; Courier Corporation: New York, NY, USA, 2000.

119. Koppel, D.E. Analysis of macromolecular polydispersity in intensity correlation spectroscopy: The method of cumulants. J. Chem. Phys. 1972, 57, 4814-4820. [CrossRef]

120. Dieckmann, Y.; Cölfen, H.; Hofmann, H.; Petri-Fink, A. Particle size distribution measurements of manganese-doped ZnS nanoparticles. Anal. Chem. 2009, 81, 3889-3895. [CrossRef] [PubMed]

121. Lange, H. Comparative test of methods to determine particle size and particle size distribution in the submicron range. Part. Part. Syst. Charact. 1995, 12, 148-157. [CrossRef]

122. Gerwert, K. Molecular reaction mechanisms of proteins monitored by time-resolved FTIR-spectroscopy. Biol. Chem. 1999, 380, 931-935. [CrossRef] [PubMed]

123. Jung, C. Insight into protein structure and protein-ligand recognition by Fourier transform infrared spectroscopy. J. Mol. Recognit. 2000, 13, 325-351. [CrossRef]

124. Kim, S.; Barry, B.A. Reaction-induced FT-IR spectroscopic studies of biological energy conversion in oxygenic photosynthesis and transport. J. Phys. Chem. B 2001, 105, 4072-4083. [CrossRef]

125. Mantele, W.G.; Wollenweber, A.M.; Nabedryk, E.; Breton, J. Infrared spectroelectrochemistry of bacteriochlorophylls and bacteriopheophytins: Implications for the binding of the pigments in the reaction center from photosynthetic bacteria. Proc. Natl. Acad. Sci. USA 1988, 85, 8468-8472. [CrossRef] [PubMed]

126. Vogel, R.; Siebert, F. Vibrational spectroscopy as a tool for probing protein function. Curr. Opin. Chem. Biol. 2000, 4, 518-523. [CrossRef]

127. Wharton, C.W. Infrared spectroscopy of enzyme reaction intermediates. Nat. Prod. Rep. 2000, 17, 447-453. [CrossRef] [PubMed]

128. Zscherp, C.; Barth, A. Reaction-induced infrared difference spectroscopy for the study of protein reaction mechanisms. Biochemistry 2001, 40, 1875-1883. [CrossRef] [PubMed]

129. Shang, L.; Wang, Y.; Jiang, J.; Dong, S. pH-dependent protein conformational changes in albumin: Gold nanoparticle bioconjugates: A spectroscopic study. Langmuir 2007, 23, 2714-2721. [CrossRef] [PubMed] 
130. Perevedentseva, E.V.; Su, F.Y.; Su, T.H.; Lin, Y.C.; Cheng, C.L.; Karmenyan, A.V.; Priezzhev, A.V.; Lugovtsov, A.E. Laser-optical investigation of the effect of diamond nanoparticles on the structure and functional properties of proteins. Quantum Electron. 2010, 40, 1089-1093. [CrossRef]

131. Baudot, C.; Tan, C.M.; Kong, J.C. FTIR spectroscopy as a tool for nano-material characterization. Infrared Phys. Technol. 2010, 53, 434-438. [CrossRef]

132. Barth, A.; Zscherp, C. What vibrations tell us about proteins. Q. Rev. Biophys. 2002, 35, 369-430. [CrossRef] [PubMed]

133. Kumar, S.; Barth, A. Following enzyme activity with infrared spectroscopy. Sensors 2010, 10, $2626-2637$. [CrossRef] [PubMed]

134. Goormaghtigh, E.; Raussens, V.; Ruysschaert, J.M. Attenuated total reflection infrared spectroscopy of proteins and lipids in biological membranes. Biochim. Biophys. Acta 1999, 1422, 105-185. [CrossRef]

135. Harrick, N.J.; Beckmann, K.H. Internal Reflection Spectroscopy. In Characterization of Solid Surfaces; Kane, P., Larrabee, G., Eds.; Springer Verlag: New York, NY, USA, 1974; pp. 215-245.

136. Hind, A.R.; Bhargava, S.K.; McKinnon, A. At the solid/liquid interface: FTIR/ATR—The tool of choice. Adv. Colloid Interface Sci. 2001, 93, 91-114. [CrossRef]

137. Johal, M.S. Understanding Nanomaterials; CRC Press: Boca Raton, FL, USA, 2011.

138. Kazarian, S.G.; Chan, K.L. Applications of ATR-FTIR spectroscopic imaging to biomedical samples. Biochim. Biophys. Acta Biomembr. 2006, 1758, 858-867. [CrossRef] [PubMed]

139. Liu, H.; Webster, T.J. Nanomedicine for implants: A review of studies and necessary experimental tools. Biomaterials 2007, 28, 354-369. [CrossRef] [PubMed]

140. Acosta, E.J.; Gonzalez, S.O.; Simanek, E.E. Synthesis, characterization, and application of melamine based dendrimers supported on silica gel. J. Polym. Sci. Polym. Chem. 2005, 43, 168-177. [CrossRef]

141. Demathieu, C.; Chehimi, M.M.; Lipskier, J.F.; Caminade, A.M.; Majoral, J.P. Characterization of dendrimers by X-ray photoelectron spectroscopy. Appl. Spectrosc. 1999, 53, 1277-1281. [CrossRef]

142. Manna, A.; Imae, T.; Aoi, K.; Okada, M.; Yogo, T. Synthesis of dendrimer-passivated noble metal nanoparticles in a polar medium: Comparison of size between silver and gold particles. Chem. Mater. 2001, 13, 1674-1681. [CrossRef]

143. Desimoni, E.; Brunetti, B. X-ray photoelectron spectroscopic characterization of chemically modified electrodes used as chemical sensors and biosensors: A review. Chemosensors 2015, 3, 70. [CrossRef]

144. Gautam, S.P.; Gupta, A.K.; Agraw, S.; Sureka, S. Spectroscopic characterization of dengrimers. Int. J. Pharm. Pharm. Sci. 2012, 4, 77-80.

145. Pawley, J. The development of field-emission scanning electron microscopy for imaging biological surfaces. Scanning 1997, 19, 324-336. [PubMed]

146. Wang, Z.L. transmission electron microscopy of shape-controlled nanocrystals and their assemblies. J. Phys. Chem. B 2000, 104, 1153-1175. [CrossRef]

147. Yao, H.; Kimura, K. Field emission scanning electron microscopy for structural characterization of 3D gold nanoparticle super lattices. In Modern Research and Educational Topics in Microscopy; Méndez-Vilas, A., Díaz, J., Eds.; Formatex Research Center: Badajoz, Spain, 2007; pp. 568-575.

148. Hall, J.B.; Dobrovolskaia, M.A.; Patri, A.K.; McNeil, S.E. Characterization of nanoparticles for therapeutics. Nanomed. Nanotechnol. Biol. Med. 2007, 2, 789-803. [CrossRef] [PubMed]

149. Ranter, B.D.; Hoffman, A.S.; Schoen, F.J.; Lemons, J.E. Biomaterials Science-An Introduction to Materials in Medicine; Elsevier: San Diego, CA, USA, 2004.

150. Williams, D.B.; Carter, C.B. The Transmission Electron Microscope; Springer Verlag: New York, NY, USA, 2009.

151. Hinterdorfer, P.; Garcia-Parajo, M.F.; Dufrene, Y.F. Single-molecule imaging of cell surfaces using near-field nanoscopy. Acc. Chem. Res. 2012, 45, 327-336. [CrossRef] [PubMed]

152. Koh, A.L.; Hu, W.; Wilson, R.J.; Wang, S.X.; Sinclair, R. TEM analyses of synthetic anti-ferromagnetic (SAF) nanoparticles fabricated using different release layers. Ultramicroscopy 2008, 108, 1490-1494. [CrossRef] [PubMed]

153. Mavrocordatos, D.; Pronk, W.; Boiler, M. Analysis of environmental particles by atomic force microscopy, scanning and transmission electron microscopy. Water Sci. Technol. 2004, 50, 9-18. [PubMed]

154. Picas, L.; Milhiet, P.E.; Hernandez-Borrell, J. Atomic force microscopy: A versatile tool to probe the physical and chemical properties of supported membranes at the nanoscale. Chem. Phys. Lipids 2012, 165, 845-860. [CrossRef] [PubMed] 
155. Song, J.; Kim, H.; Jang, Y.; Jang, J. Enhanced Antibacterial Activity of silver/polyrhodanine-composite-decorated silica nanoparticles. ACS Appl. Mater. Interfaces 2013, 5, 11563-11568. [CrossRef] [PubMed]

156. Parot, P.; Dufrene, Y.F.; Hinterdorfer, P.; Le, G.; Rimellec, C.; Navajas, D.; Pellequer, J.L.; Scheuring, S. Past, present and future of atomic force microscopy in life sciences and medicine. J. Mol. Recognit. 2007, 20, 418-431. [CrossRef] [PubMed]

157. Yang, L.; Watts, D.J. Particle surface characteristics may play an important role in phytotoxicity of alumina nanoparticles. Toxicol. Lett. 2005, 158, 122-132. [CrossRef] [PubMed]

158. Tiede, K.; Boxall, A.B.; Tear, S.P.; Lewis, J.; David, H.; Hassellov, M. Detection and characterization of engineered nanoparticles in food and the environment. Food Addit. Contam. Part A Chem. Anal. Control Expo. Risk Assess. 2008, 25, 795-821. [CrossRef] [PubMed]

159. Gmoshinski, I.V.; Khotimchenko, S.A.; Popov, V.O.; Dzantiev, B.B.; Zherdev, A.V.; Demin, V.F.; Buzulukov, Y.P. Nanomaterials and nanotechnologies: Methods of analysis and control. Russ. Chem. Rev. 2013, 82, 48-76. [CrossRef]

160. Bhushan, B.; Marti, O. Scanning probe microscopy_Principle of operation, instrumentation, and probes. In Springer Handbook of Nanotechnology; Bhushan, B., Ed.; Springer Verlag: Berlin, Germany, 2004; pp. 325-369.

161. Sönnichsen, C.; Reinhard, B.M.; Liphardt, J.; Alivisatos, A.P. A molecular ruler based on plasmon coupling of single gold and silver nanoparticles. Nat. Biotechnol. 2005, 23, 741-745. [CrossRef] [PubMed]

162. Sannomiya, T.; Hafner, C.; Voros, J. In situ sensing of single binding events by localized surface plasmon resonance. Nano Lett. 2008, 8, 3450-3455. [CrossRef] [PubMed]

163. Li, C.; Wu, C.; Zheng, J.S.; Lai, J.P.; Zhang, C.L.; Zhao, Y.B. LSPR sensing of molecular biothiols based on noncoupled gold nanorods. Langmuir 2010, 26, 9130-9135. [CrossRef] [PubMed]

164. Shopova, S.I.; Rajmangal, R.; Holler, S.; Arnold, S. Plasmonic enhancement of a whispering-gallery-mode biosensor for single nanoparticle detection. Appl. Phys. Lett. 2011, 98, 243104. [CrossRef]

165. Zijlstra, P.; Paulo, P.M.; Orrit, M. Optical detection of single non-absorbing molecules using the surface plasmon resonance of a gold nanorod. Nat. Nanotechnol. 2012, 7, 379-382. [CrossRef] [PubMed]

166. Lis, D.; Cecchet, F. Localized surface plasmon resonances in nanostructures to enhance nonlinear vibrational spectroscopies: Towards an astonishing molecular sensitivity. Beilstein J. Nanotechnol. 2014, 5, 2275-2292. [CrossRef] [PubMed]

167. Gliga, A.R.; Skoglund, S.; Wallinder, I.O.; Fadeel, B.; Karlsson, H.L. Size-dependent cytotoxicity of silver nanoparticles in human lung cells: The role of cellular uptake, agglomeration and Ag release. Part. Fiber Toxicol. 2014, 11, 11. [CrossRef] [PubMed]

168. Han, J.W.; Gurunathan, S.; Jeong, J.K.; Choi, Y.J.; Kwon, D.N.; Park, J.K.; Kim, J.H. Oxidative stress mediated cytotoxicity of biologically synthesized silver nanoparticles in human lung epithelial adenocarcinoma cell line. Nanoscale Res. Lett. 2014, 9, 459. [CrossRef] [PubMed]

169. Johnston, H.J.; Hutchison, G.; Christensen, F.M.; Peters, S.; Hankin, S.; Stone, V. A review of the in vivo and in vitro toxicity of silver and gold particulates: Particle attributes and biological mechanisms responsible for the observed toxicity. Crit. Rev. Toxicol. 2010, 40, 328-346. [CrossRef] [PubMed]

170. Liu, H.L.; Dai, S.A.; Fu, K.Y.; Hsu, S.H. Antibacterial properties of silver nanoparticles in three different sizes and their nanocomposites with a new waterborne polyurethane. Int. J. Nanomed. 2010, 5, 1017-1028.

171. Loza, K.; Diendorf, J.; Sengstock, C.; Ruiz-Gonzalez, L.; Gonzalez-Calbet, J.M.; Vallet-Regi, M.; Köllerb, M.; Epple, M. The dissolution and biological effects of silver nanoparticles in biological media. J. Mater. Chem. B 2014, 2, 1634-1643. [CrossRef]

172. Misra, R.D.; Girase, B.; Depan, D.; Shah, J.S. Hybrid nanoscale architecture for enhancement of antimicrobial activity: Immobilization of silver nanoparticles on thiol-functionalized polymer crystallized on carbon nanotubes. Adv. Eng. Mater. 2012, 14, B93-B100. [CrossRef]

173. Park, M.V.; Neigh, A.M.; Vermeulen, J.P.; de la Fonteyne, L.J.; Verharen, H.W.; Briedé, J.J.; van Loveren, H.; de Jong, W.H. The effect of particle size on the cytotoxicity, inflammation, developmental toxicity and genotoxicity of silver nanoparticles. Biomaterials 2011, 32, 9810-9817. [CrossRef] [PubMed]

174. Powers, C.M.; Badireddy, A.R.; Ryde, I.T.; Seidler, F.J.; Slotkin, T.A. Silver nanoparticles compromise neurodevelopment in PC12 cells: Critical contributions of silver ion, particle size, coating, and composition. Environ. Health Perspect. 2011, 119, 37-44. [CrossRef] [PubMed]

175. Wei, L.Y.; Lu, J.R.; Xu, H.Z.; Patel, A.; Chen, Z.S.; Chen, G.F. Silver nanoparticles: Synthesis, properties, and therapeutic applications. Drug Discov. Today 2015, 20, 595-601. [CrossRef] [PubMed] 
176. Sriram, M.I.; Kalishwaralal, K.; Barathmanikanth, S.; Gurunathani, S. Size-based cytotoxicity of silver nanoparticles in bovine retinal endothelial cells. Nanosci. Methods 2012, 1, 56-77. [CrossRef]

177. Stoehr, L.C.; Gonzalez, E.; Stampfl, A.; Casals, E.; Duschl, A.; Puntes, V.; Oostingh, G.J. Shape matters: Effects of silver nanospheres and wires on human alveolar epithelial cells. Part. Fiber Toxicol. 2011, 8, 36. [CrossRef] [PubMed]

178. Rycenga, M.; Cobley, C.M.; Zeng, J.; Li, W.; Moran, C.H.; Zhang, Q.; Qin, D.; Xia, Y. Controlling the synthesis and assembly of silver nanostructures for plasmonic applications. Chem. Rev. 2011, 111, 3669-3712. [CrossRef] [PubMed]

179. Suresh, A.K.; Pelletier, D.A.; Wang, W.; Morrell-Falvey, J.L.; Gu, B.H.; Doktycz, M.J. Cytotoxicity induced by engineered silver nanocrystallites is dependent on surface coatings and cell Types. Langmuir 2012, 28, 2727-2735. [CrossRef] [PubMed]

180. Tabata, Y.; Ikada, Y. Macrophage phagocytosis of biodegradable microspheres composed of L-lactic acid/glycolic acid homo- and copolymers. J. Biomed. Mater. Res. 1988, 22, 837-858. [CrossRef] [PubMed]

181. Schlinkert, P.; Casals, E.; Boyles, M.; Tischler, U.; Hornig, E.; Tran, N.; Zhao, J.; Himly, M.; Riediker, M.; Oostingh, G.J.; et al. The oxidative potential of differently charged silver and gold nanoparticles on three human lung epithelial cell types. J. Nanobiotechnol. 2015, 13, 1. [CrossRef] [PubMed]

182. Tiyaboonchai, W. Chitosan nanoparticles: A promising system for drug delivery. Naresuan Univ. J. 2003, 11, 51-66.

183. Baker, C.; Pradhan, A.; Pakstis, L.; Pochan, D.J.; Shah, S.I. Synthesis and antibacterial properties of silver nanoparticles. J. Nanosci. Nanotechnol. 2005, 5, 244-249. [CrossRef] [PubMed]

184. Kim, J.S.; Kuk, E.; Yu, K.N.; Kim, J.H.; Park, S.J.; Lee, H.J.; Kim, S.H.; Park, Y.K.; Park, Y.H.; Hwang, C.Y.; et al. Antimicrobial effects of silver nanoparticles. Nanomedicine 2007, 3, 95-101. [CrossRef] [PubMed]

185. Shahverdi, A.R.; Fakhimi, A.; Shahverdi, H.R.; Minaian, S. Synthesis and effect of silver nanoparticles on the antibacterial activity of different antibiotics against Staphylococcus aureus and Escherichia coli. Nanomedicine 2007, 3, 168-171. [CrossRef] [PubMed]

186. Sanpui, P.; Murugadoss, A.; Prasad, P.V.; Ghosh, S.S.; Chattopadhyay, A. The antibacterial properties of a novel chitosan-Ag-nanoparticle composite. Int. J. Food Microbiol. 2008, 124, 142-146. [CrossRef] [PubMed]

187. Nanda, A.; Saravanan, M. Biosynthesis of silver nanoparticles from Staphylococcus aureus and its antimicrobial activity against MRSA and MRSE. Nanomedicine 2009, 5, 452-456. [CrossRef] [PubMed]

188. Pal, S.; Yoon, E.J.; Tak, Y.K.; Choi, E.C.; Song, J.M. Synthesis of highly antibacterial nanocrystalline trivalent silver polydiguanide. J. Am. Chem. Soc. 2009, 131, 16147-16155. [CrossRef] [PubMed]

189. Kalishwaralal, K.; BarathManiKanth, S.; Pandian, S.R.; Deepak, V.; Gurunathan, S. Silver nanoparticles impede the biofilm formation by Pseudomonas aeruginosa and Staphylococcus epidermidis. Colloid Surface B 2010, 79, 340-344. [CrossRef] [PubMed]

190. Parashar, U.K.; Kumar, V.; Bera, T.; Saxena, P.S.; Nath, G.; Srivastava, S.K.; Giri, R.; Srivastava, A. Study of mechanism of enhanced antibacterial activity by green synthesis of silver nanoparticles. Nanotechnology 2011, 22, 415104. [CrossRef] [PubMed]

191. Besinis, A.; De Peralta, T.; Handy, R.D. The antibacterial effects of silver, titanium dioxide and silica dioxide nanoparticles compared to the dental disinfectant chlorhexidine on Streptococcus mutans using a suite of bioassays. Nanotoxicology 2014, 8, 1-16. [CrossRef] [PubMed]

192. Agnihotri, S.; Mukherji, S.; Mukherji, S. Immobilized silver nanoparticles enhance contact killing and show highest efficacy: Elucidation of the mechanism of bactericidal action of silver. Nanoscale 2013, 5, 7328-7340. [CrossRef] [PubMed]

193. Khurana, C.; Vala, A.K.; Andhariya, N.; Pandey, O.P.; Chudasama, B. Antibacterial activity of silver: The role of hydrodynamic particle size at nanoscale. J. Biomed. Mater. Res. A 2014, 102, 3361-3368. [CrossRef] [PubMed]

194. Chen, Q.C.; Jiang, H.J.; Ye, H.L.; Li, J.R.; Huang, J.Y. Preparation, antibacterial, and antioxidant activities of silver/chitosan composites. J. Carbohydr. Chem. 2014, 33, 298-312. [CrossRef]

195. Shao, W.; Liu, X.F.; Min, H.H.; Dong, G.H.; Feng, Q.Y.; Zuo, S.L. Preparation, characterization, and antibacterial activity of silver nanoparticle-decorated graphene oxide nanocomposite. ACS Appl. Mater. Interfaces 2015, 7, 6966-6973. [CrossRef] [PubMed] 
196. De Moraes, A.C.; Lima, B.A.; de Faria, A.F.; Brocchi, M.; Alves, O.L. Graphene oxide-silver nanocomposite as a promising biocidal agent against methicillin-resistant Staphylococcus aureus. Int. J. Nanomed. 2015, 10, 6847-6861. [CrossRef] [PubMed]

197. Eckhardt, S.; Brunetto, P.S.; Gagnon, J.; Priebe, M.; Giese, B.; Fromm, K.M. nanobio silver: Its interactions with peptides and bacteria, and its uses in medicine. Chem. Rev. 2013, 113, 4708-4754. [CrossRef] [PubMed]

198. Kim, K.J.; Sung, W.S.; Moon, S.K.; Choi, J.S.; Kim, J.G.; Lee, D.G. Antifungal effect of silver nanoparticles on dermatophytes. J. Microbiol. Biotechnol. 2008, 18, 1482-1484. [PubMed]

199. Esteban-Tejeda, L.; Malpartida, F.; Esteban-Cubillo, A.; Pecharroman, C.; Moya, J.S. The antibacterial and antifungal activity of a soda-lime glass containing silver nanoparticles. Nanotechnology 2009, 20, 085103. [CrossRef] [PubMed]

200. Jain, J.; Arora, S.; Rajwade, J.M.; Omray, P.; Khandelwal, S.; Paknikar, K.M. Silver nanoparticles in therapeutics: Development of an antimicrobial gel formulation for topical use. Mol. Pharm. 2009, 6, 1388-1401. [CrossRef] [PubMed]

201. Gajbhiye, M.; Kesharwani, J.; Ingle, A.; Gade, A.; Rai, M. Fungus-mediated synthesis of silver nanoparticles and their activity against pathogenic fungi in combination with fluconazole. Nanomedicine 2009, 5, 382-386. [CrossRef] [PubMed]

202. Monteiro, D.R.; Silva, S.; Negri, M.; Gorup, L.F.; de Camargo, E.R.; Oliveira, R.; Barbosa, D.B.; Henriques, M. Silver nanoparticles: Influence of stabilizing agent and diameter on antifungal activity against Candida albicans and Candida glabrata biofilms. Lett. Appl. Microbiol. 2012, 54, 383-391. [CrossRef] [PubMed]

203. Krishnaraj, C.; Ramachandran, R.; Mohan, K.; Kalaichelvan, P.T. Optimization for rapid synthesis of silver nanoparticles and its effect on phytopathogenic fungi. Spectrochim. Acta A 2012, 93, 95-99. [CrossRef] [PubMed]

204. Gopinath, V.; Velusamy, P. Extracellular biosynthesis of silver nanoparticles using Bacillus sp GP-23 and evaluation of their antifungal activity towards Fusarium oxysporum. Spectrochim. Acta A 2013, 106, 170-174. [CrossRef] [PubMed]

205. Li, C.; Wang, X.S.; Chen, F.; Zhang, C.; Zhi, X.; Wang, K.; Cui, D. The antifungal activity of graphene oxide-silver nanocomposites. Biomaterials 2013, 34, 3882-3890. [CrossRef] [PubMed]

206. Monteiro, D.R.; Silva, S.; Negri, M.; Gorup, L.F.; de Camargo, E.R.; Oliveira, R.; Barbosa, D.B.; Henriques, M. Antifungal activity of silver nanoparticles in combination with nystatin and chlorhexidine digluconate against Candida albicans and Candida glabrata biofilms. Mycoses 2013, 56, 672-680. [CrossRef] [PubMed]

207. Mishra, S.; Singh, B.R.; Singh, A.; Keswani, C.; Naqvi, A.H.; Singh, H.B. Biofabricated silver nanoparticles act as a strong fungicide against Bipolaris sorokiniana causing spot blotch disease in wheat. PLoS ONE 2014, 9, e97881. [CrossRef] [PubMed]

208. Ogar, A.; Tylko, G.; Turnau, K. Antifungal properties of silver nanoparticles against indoor mould growth. Sci. Total Environ. 2015, 521, 305-314. [CrossRef] [PubMed]

209. Elechiguerra, J.L.; Burt, J.L.; Morones, J.R.; Camacho-Bragado, A.; Gao, X.; Lara, H.H.; Yacaman, M.J. Interaction of silver nanoparticles with HIV-1. J. Nanobiotechnol. 2005, 3, 6. [CrossRef] [PubMed]

210. Lok, C.N.; Ho, C.M.; Chen, R.; He, Q.Y.; Yu, W.Y.; Sun, H.; Tam, P.K.; Chiu, J.F.; Che, C.M. Proteomic analysis of the mode of antibacterial action of silver nanoparticles. J. Proteome Res. 2006, 5, 916-924. [CrossRef] [PubMed]

211. Lara, H.H.; Ayala-Nunez, N.V.; Ixtepan-Turrent, L.; Rodriguez-Padilla, C. Mode of antiviral action of silver nanoparticles against HIV-1. J. Nanobiotechnol. 2010, 8, 1. [CrossRef] [PubMed]

212. Xiang, D.X.; Chen, Q.; Pang, L.; Zheng, C.L. Inhibitory effects of silver nanoparticles on H1N1 influenza A virus in vitro. J. Virol. Methods 2011, 178, 137-142. [CrossRef] [PubMed]

213. Fayaz, A.M.; Ao, Z.; Girilal, M.; Chen, L.; Xiao, X.; Kalaichelvan, P.; Yao, X. Inactivation of microbial infectiousness by silver nanoparticles-coated condom: A new approach to inhibit HIV- and HSV-transmitted infection. Int. J. Nanomed. 2012, 7, 5007-5018.

214. Trefry, J.C.; Wooley, D.P. Silver nanoparticles inhibit vaccinia virus infection by preventing viral entry through a macropinocytosis-dependent mechanism. J. Biomed. Nanotechnol. 2013, 9, 1624-1635. [CrossRef] [PubMed]

215. Xiang, D.X.; Zheng, Y.; Duan, W.; Li, X.; Yin, J.; Shigdar, S.; O'Connor, M.L.; Marappan, M.; Zhao, X.; Miao, Y.; et al. Inhibition of A/Human/Hubei/3/2005 $\left(\mathrm{H}_{3} \mathrm{~N}_{2}\right)$ influenza virus infection by silver nanoparticles in vitro and in vivo. Int. J. Nanomed. 2013, 8, 4103-4113. [CrossRef] [PubMed] 
216. Gaikwad, S.; Ingle, A.; Gade, A.; Rai, M.; Falanga, A.; Incoronato, N.; Russo, L.; Galdiero, S.; Galdiero, M. Antiviral activity of mycosynthesized silver nanoparticles against herpes simplex virus and human parainfluenza virus type 3. Int. J. Nanomed. 2013, 8, 4303-4314.

217. Khandelwal, N.; Kaur, G.; Chaubey, K.K.; Singh, P.; Sharma, S.; Tiwari, A.; Singh, S.V.; Kumar, N. Silver nanoparticles impair Peste des petits ruminants virus replication. Virus Res. 2014, 190, 1-7. [CrossRef] [PubMed]

218. Orlowski, P.; Tomaszewska, E.; Gniadek, M.; Baska, P.; Nowakowska, J.; Sokolowska, J.; Nowak, Z.; Donten, M.; Celichowski, G.; Grobelny, J.; et al. Tannic acid modified silver nanoparticles show antiviral activity in herpes simplex virus type 2 infection. PLoS ONE 2014, 9, e104113. [CrossRef] [PubMed]

219. Swathy, J.R.; Sankar, M.U.; Chaudhary, A.; Aigal, S.; Anshup; Pradeep, T. Antimicrobial silver: An unprecedented anion effect. Sci. Rep. 2014, 4, 7161. [CrossRef] [PubMed]

220. Elbeshehy, E.K.F.; Elazzazy, A.M.; Aggelis, G. Silver nanoparticles synthesis mediated by new isolates of Bacillus spp., nanoparticle characterization and their activity against Bean Yellow Mosaic Virus and human pathogens. Front. Microbiol. 2015, 6, 453. [CrossRef] [PubMed]

221. Eming, S.A.; Krieg, T.; Davidson, J.M. Inflammation in wound repair: Molecular and cellular mechanisms. J. Investig. Dermatol. 2007, 127, 514-525. [CrossRef] [PubMed]

222. Wong, C.K.; Cheung, P.F.; Ip, W.K.; Lam, C.W. Intracellular signaling mechanisms regulating toll-like receptor-mediated activation of eosinophils. Am. J. Respir. Cell Mol. Biol. 2007, 37, 85-96. [CrossRef] [PubMed]

223. Broughton, G.; Janis, J.E.; Attinger, C.E. The basic science of wound healing. Plast. Reconstr. Surg. 2006, 117, 12s-34s. [CrossRef] [PubMed]

224. Witte, M.B.; Barbul, A. General principles of wound healing. Surg. Clin. N. Am. 1997, 77, 509-528. [CrossRef]

225. Bhol, K.C.; Schechter, P.J. Effects of nanocrystalline silver (NPI 32101) in a rat model of ulcerative colitis. Dig. Dis. Sci. 2007, 52, 2732-2742. [CrossRef] [PubMed]

226. Tian, J.; Wong, K.K.; Ho, C.M.; Lok, C.N.; Yu, W.Y.; Che, C.M.; Chiu, J.F.; Tam, P.K. Topical delivery of silver nanoparticles promotes wound healing. ChemMedChem 2007, 2, 129-136. [CrossRef] [PubMed]

227. Nadworny, P.L.; Landry, B.K.; Wang, J.; Tredget, E.E.; Burrell, R.E. Does nanocrystalline silver have a transferable effect? Wound Repair Regen. 2010, 18, 254-265. [CrossRef] [PubMed]

228. David, L.; Moldovan, B.; Vulcu, A.; Olenic, L.; Perde-Schrepler, M.; Fischer-Fodor, E.; Florea, A.; Crisan, M.; Chiorean, I.; Clichici, S.; et al. Green synthesis, characterization and anti-inflammatory activity of silver nanoparticles using European black elderberry fruits extract. Colloids Surfaces B Biointerfaces 2014, 122, 767-777. [CrossRef] [PubMed]

229. Carmeliet, P.; Jain, R.K. Angiogenesis in cancer and other diseases. Nature 2000, 407, 249-257. [CrossRef] [PubMed]

230. Timar, J.; Dome, B.; Fazekas, K.; Janovics, A.; Paku, S. Angiogenesis-dependent diseases and angiogenesis therapy. Pathol. Oncol. Res. 2001, 7, 85-94. [CrossRef] [PubMed]

231. Kalishwaralal, K.; Banumathi, E.; Ram Kumar Pandian, S.; Deepak, V.; Muniyandi, J.; Eom, S.H.; Gurunathan, S. Silver nanoparticles inhibit VEGF induced cell proliferation and migration in bovine retinal endothelial cells. Colloids Surf. B Biointerfaces 2009, 73, 51-57. [CrossRef] [PubMed]

232. Kemp, M.M.; Kumar, A.; Mousa, S.; Dyskin, E.; Yalcin, M.; Ajayan, P.; Linhardt, R.J.; Mousa, S.A. Gold and silver nanoparticles conjugated with heparin derivative possess anti-angiogenesis properties. Nanotechnology 2009, 20, 455104. [CrossRef] [PubMed]

233. Kim, H.; Choi, J.S.; Kim, K.S.; Yang, J.A.; Joo, C.K.; Hahn, S.K. Flt1 peptide-hyaluronate conjugate micelle-like nanoparticles encapsulating genistein for the treatment of ocular neovascularization. Acta Biomater. 2012, 8 , 3932-3940. [CrossRef] [PubMed]

234. Baharara, J.; Namvar, F.; Mousavi, M.; Ramezani, T.; Mohamad, R. Anti-angiogenesis effect of biogenic silver nanoparticles synthesized using saliva officinalis on chick chorioalantoic membrane (CAM). Molecules 2014, 19, 13498-13508. [CrossRef] [PubMed]

235. Thorley, A.J.; Tetley, T.D. New perspectives in nanomedicine. Pharmacol. Ther. 2013, 140, 176-185. [CrossRef] [PubMed]

236. Gopinath, P.; Gogoi, S.K.; Chattopadhyay, A.; Ghosh, S.S. Implications of silver nanoparticle induced cell apoptosis for in vitro gene therapy. Nanotechnology 2008, 19, 075104. [CrossRef] [PubMed]

237. AshaRani, P.V.; Mun, G.L.K.; Hande, M.P.; Valiyaveettil, S. Cytotoxicity and genotoxicity of silver nanoparticles in human cells. ACS Nano 2009, 3, 279-290. [CrossRef] [PubMed] 
238. Jun, B.H.; Noh, M.S.; Kim, J.; Kim, G.; Kang, H.; Kim, M.S.; Seo, Y.T.; Baek, J.; Kim, J.H.; Park, J.; et al. Multifunctional silver-embedded magnetic nanoparticles as SERS nanoprobes and their applications. Small 2010, 6, 119-125. [CrossRef] [PubMed]

239. Wang, H.J.; Yang, L.; Yang, H.Y.; Wang, K.; Yao, W.G.; Jiang, K.; Huang, X.L.; Zheng, Z. Antineoplastic activities of protein-conjugated silver sulfide nano-crystals with different shapes. J. Inorg. Biochem. 2010, 104, 87-91. [CrossRef] [PubMed]

240. Sanpui, P.; Chattopadhyay, A.; Ghosh, S.S. Induction of apoptosis in cancer cells at low silver nanoparticle concentrations using chitosan nanocarrier. ACS Appl. Mater. Interfaces 2011, 3, 218-228. [CrossRef] [PubMed]

241. Boca, S.C.; Potara, M.; Gabudean, A.M.; Juhem, A.; Baldeck, P.L.; Astilean, S. Chitosan-coated triangular silver nanoparticles as a novel class of biocompatible, highly effective photothermal transducers for in vitro cancer cell therapy. Cancer Lett. 2011, 311, 131-140. [CrossRef] [PubMed]

242. Guo, D.; Zhu, L.; Huang, Z.; Zhou, H.; Ge, Y.; Ma, W.; Wu, J.; Zhang, X.; Zhou, X.; Zhang, Y.; et al. Anti-leukemia activity of PVP-coated silver nanoparticles via generation of reactive oxygen species and release of silver ions. Biomaterials 2013, 34, 7884-7894. [CrossRef] [PubMed]

243. Gurunathan, S.; Han, J.W.; Eppakayala, V.; Jeyaraj, M.; Kim, J.H. Cytotoxicity of biologically synthesized silver nanoparticles in MDA-MB-231 human breast cancer cells. BioMed Res. Int. 2013, 2013, 535796. [CrossRef] [PubMed]

244. Locatelli, E.; Naddaka, M.; Uboldi, C.; Loudos, G.; Fragogeorgi, E.; Molinari, V.; Pucci, A.; Tsotakos, T.; Psimadas, D.; Ponti, J.; et al. Targeted delivery of silver nanoparticles and alisertib: In vitro and in vivo synergistic effect against glioblastoma. Nanomedicine 2014, 9, 839-849. [CrossRef] [PubMed]

245. Ortega, F.G.; Fernández-Baldo, M.A.; Fernández, J.G.; Serrano, M.J.; Sanz, M.I.; Diaz-Mochón, J.J.; Lorente, J.A.; Raba, J. Study of antitumor activity in breast cell lines using silver nanoparticles produced by yeast. Int. J. Nanomed. 2015, 10, 2021-2031.

246. Banti, C.N.; Hadjikakou, S.K. Anti-proliferative and anti-tumor activity of silver(I) compounds. Metallomics 2013, 5, 569. [CrossRef] [PubMed]

247. Kelkar, S.S.; Reineke, T.M. Theranostics: Combining imaging and therapy. Bioconjug. Chem. 2011, 22, 1879-1903. [CrossRef] [PubMed]

248. Meyers, D.D.; Cottone, R.R. Solution-focused therapy as a culturally acknowledging approach with america. J. Multicult. Couns. Dev. 2013, 41, 47-55. [CrossRef]

249. Liu, J.Y.; Wang, Z.Y.; Liu, F.D.; Kane, A.B.; Hurt, R.H. chemical transformations of nanosilver in biological environments. ACS Nano 2012, 6, 9887-9899. [CrossRef] [PubMed]

250. Etheridge, M.L.; Campbell, S.A.; Erdman, A.G.; Haynes, C.L.; Wolf, S.M.; McCullough, J. The big picture on small medicine: The state of nanomedicine products approved for use or in clinical trials. Nanomedicine 2013, 9, 1-14. [PubMed]

251. Ge, L.P.; Li, Q.T.; Wang, M.; Yang, J.O.; Li, X.J.; Xing, M.M.Q. Nanosilver particles in medical applications: Synthesis, performance, and toxicity. Int. J. Nanomed. 2014, 9, 2399-2407.

252. Zhou, W.; Ma, Y.Y.; Yang, H.; Ding, Y.; Luo, X.G. A label-free biosensor based on silver nanoparticles array for clinical detection of serum p53 in head and neck squamous cell carcinoma. Int. J. Nanomed. 2011, 6, 381-386. [CrossRef] [PubMed]

253. Loo, C.; Lowery, A.; Halas, N.; West, J.; Drezek, R. Immunotargeted nanoshells for integrated cancer imaging and therapy. Nano Lett. 2005, 5, 709-711. [CrossRef] [PubMed]

254. Asharani, P.; Sethu, S.; Lim, H.K.; Balaji, G.; Valiyaveettil, S.; Hande, M.P. Differential regulation of intracellular factors mediating cell cycle, DNA repair and inflammation following exposure to silver nanoparticles in human cells. Genome Integr. 2012, 3, 2. [CrossRef] [PubMed]

255. Foldbjerg, R.; Irving, E.S.; Hayashi, Y.; Sutherland, D.S.; Thorsen, K.; Autrup, H.; Beer, C. Global gene expression profiling of human lung epithelial cells after exposure to nanosilver. Toxicol. Sci. 2012, 130, 145-157. [CrossRef] [PubMed]

256. Lin, J.; Huang, Z.; Wu, H.; Zhou, W.; Jin, P.; Wei, P.; Zhang, Y.; Zheng, F.; Zhang, J.; Xu, J.; et al. Inhibition of autophagy enhances the anticancer activity of silver nanoparticles. Autophagy 2014, 10, 2006-2020. [CrossRef] [PubMed]

257. Ahamed, M.; Karns, M.; Goodson, M.; Rowe, J.; Hussain, S.M.; Schlager, J.J.; Hong, Y. DNA damage response to different surface chemistry of silver nanoparticles in mammalian cells. Toxicol. Appl. Pharmacol. 2008, 233, 404-410. [CrossRef] [PubMed] 
258. Gurunathan, S.; Raman, J.; Malek, N.A.; John, P.A.; Vikineswary, S. Green synthesis of silver nanoparticles using Ganoderma neo-japonicum Imazeki: A potential cytotoxic agent against breast cancer cells. Int. J. Nanomed. 2013, 8, 4399-4413.

259. Piao, M.J.; Kang, K.A.; Lee, I.K.; Kim, H.S.; Kim, S.; Choi, J.Y.; Choi, J.; Hyun, J.W. Silver nanoparticles induce oxidative cell damage in human liver cells through inhibition of reduced glutathione and induction of mitochondria-involved apoptosis. Toxicol. Lett. 2011, 201, 92-100. [CrossRef] [PubMed]

260. De Matteis, V.; Malvindi, M.A.; Galeone, A.; Brunetti, V.; De Luca, E.; Kote, S.; Kshirsagar, P.; Sabella, S.; Bardi, G.; Pompa, P.P. Negligible particle-specific toxicity mechanism of silver nanoparticles: The role of $\mathrm{Ag}^{+}$ ion release in the cytosol. Nanomedicine 2015, 11, 731-739. [CrossRef] [PubMed]

261. Hatipoglu, M.K.; Kelestemur, S.; Altunbek, M.; Culha, M. Source of cytotoxicity in a colloidal silver nanoparticle suspension. Nanotechnology 2015, 26, 195103. [CrossRef] [PubMed]

262. Zuberek, M.; Wojciechowska, D.; Krzyzanowski, D.; Meczynska-Wielgosz, S.; Kruszewski, M.; Grzelak, A. Glucose availability determines silver nanoparticles toxicity in $\mathrm{HepG}_{2}$. J. Nanobiotechnol. 2015, $13,72$. [CrossRef] [PubMed]

263. Lim, J.K.; Tilton, R.D.; Eggeman, A.; Majetich, S.A. Design and synthesis of plasmonic magnetic nanoparticles. J. Magn. Magn. Mater. 2007, 311, 78-83. [CrossRef]

264. Huang, Y.F.; Sefah, K.; Bamrungsap, S.; Chang, H.T.; Tan, W. Selective photothermal therapy for mixed cancer cells using aptamer-conjugated nanorods. Langmuir 2008, 24, 11860-11865. [CrossRef] [PubMed]

265. Rai, P.; Mallidi, S.; Zheng, X.; Rahmanzadeh, R.; Mir, Y.; Elrington, S.; Khurshid, A.; Hasan, T. Development and applications of photo-triggered theranostic agents. Adv. Drug Deliv. Rev. 2010, 62, 1094-1124. [CrossRef] [PubMed]

266. Khlebtsov, B.; Panfilova, E.; Khanadeev, V.; Bibikova, O.; Terentyuk, G.; Ivanov, A.; Rumyantseva, V.; Shilov, I.; Ryabova, A.; Loshchenov, V.; et al. Nanocomposites containing silica-coated gold-silver nanocages and $\mathrm{Yb}$-2,4-dimethoxyhematoporphyrin: Multifunctional capability of IR-luminescence detection, photosensitization, and photothermolysis. ACS Nano 2011, 5, 7077-7089. [CrossRef] [PubMed]

267. Wang, Y.L.; Newell, B.B.; Irudayaraj, J. Folic acid protected silver nanocarriers for targeted drug delivery. J. Biomed. Nanotechnol. 2012, 8, 751-759. [CrossRef] [PubMed]

268. Fang, C.; Kievit, F.M.; Cho, Y.C.; Mok, H.; Press, O.W.; Zhang, M.Q. Effect of cationic side-chains on intracellular delivery and cytotoxicity of $\mathrm{pH}$ sensitive polymer-doxorubicin nanocarriers. Nanoscale 2012, 4, 7012-7020. [CrossRef] [PubMed]

269. Locatelli, E.; Broggi, F.; Ponti, J.; Marmorato, P.; Franchini, F.; Lena, S.; Franchini, M.C. Lipophilic silver nanoparticles and their polymeric entrapment into targeted-PEG-based micelles for the treatment of glioblastoma. Adv. Healthc. Mater. 2012, 1, 342-347. [CrossRef] [PubMed]

270. Menon, J.U.; Jadeja, P.; Tambe, P.; Vu, K.; Yuan, B.H.; Nguyen, K.T. Nanomaterials for photo-based diagnostic and therapeutic applications. Theranostics 2013, 3, 152-166. [CrossRef] [PubMed]

271. Wu, P.; Gao, Y.; Lu, Y.M.; Zhang, H.; Cai, C.X. High specific detection and near-infrared photothermal therapy of lung cancer cells with high SERS active aptamer-silver-gold shell-core nanostructures. Analyst 2013, 138, 6501-6510. [CrossRef] [PubMed]

272. Liu, P.; Huang, Z.; Chen, Z.; Xu, R.; Wu, H.; Zang, F.; Wang, C.; Gu, N. Silver nanoparticles: A novel radiation sensitizer for glioma? Nanoscale 2013, 5, 11829-11836. [CrossRef] [PubMed]

273. Kleinauskas, A.; Rocha, S.; Sahu, S.; Sun, Y.P.; Juzenas, P. Carbon-core silver-shell nanodots as sensitizers for phototherapy and radiotherapy. Nanotechnology 2013, 24, 325103. [CrossRef] [PubMed]

274. Boca-Farcau, S.; Potara, M.; Simon, T.; Juhem, A.; Baldeck, P.; Astilean, S. Folic acid-conjugated, SERS-labeled silver nanotriangles for multimodal detection and targeted photothermal treatment on human ovarian cancer cells. Mol. Pharmacol. 2014, 11, 391-399. [CrossRef] [PubMed]

275. Mukherjee, S.; Chowdhury, D.; Kotcherlakota, R.; Patra, S.; B, V.; Bhadra, M.P.; Sreedhar, B.; Patra, C.R. Potential theranostics application of bio-synthesized silver nanoparticles (4-in-1 system). Theranostics 2014, 4, 316-335. [CrossRef] [PubMed]

276. Yamada, M.; Foote, M.; Prow, T.W. Therapeutic gold, silver, and platinum nanoparticles. Wires Nanomed. Nanobiotechnol. 2015, 7, 428-445. [CrossRef] [PubMed]

277. Kamaly, N.; Xiao, Z.; Valencia, P.M.; Radovic-Moreno, A.F.; Farokhzad, O.C. Targeted polymeric therapeutic nanoparticles: Design, development and clinical translation. Chem. Soc. Rev. 2012, 41, 2971-3010. [CrossRef] [PubMed] 
278. Douillard, J.Y.; Gervais, R.; Dabouis, G.; Le Groumellec, A.; D'Arlhac, M.; Spaeth, D.; Coudert, B.; Caillaud, D.; Monnier, A.; Clary, C.; et al. Sequential two-line strategy for stage IV non-small-cell lung cancer: Docetaxel-cisplatin versus vinorelbine-cisplatin followed by cross-over to single-agent docetaxel or vinorelbine at progression: Final results of a randomised phase II study. Ann. Oncol. 2005, 16, 81-89. [CrossRef] [PubMed]

279. Ma, L.; Kohli, M.; Smith, A. Nanoparticles for combination drug therapy. ACS Nano 2013, 7, 9518-9525. [CrossRef] [PubMed]

280. Singh, S.; Chitkara, D.; Mehrazin, R.; Behrman, S.W.; Wake, R.W.; Mahato, R.I. Chemoresistance in prostate cancer cells is regulated by miRNAs and Hedgehog pathway. PLoS ONE 2012, 7, e40021. [CrossRef] [PubMed]

281. Fanciullino, R.; Ciccolini, J.; Milano, G. Challenges, expectations and limits for nanoparticles-based therapeutics in cancer: A focus on nano-albumin-bound drugs. Crit. Rev. Oncol. Hematol. 2013, 88, 504-513. [CrossRef] [PubMed]

282. Wicki, A.; Witzigmann, D.; Balasubramanian, V.; Huwyler, J. Nanomedicine in cancer therapy: Challenges, opportunities, and clinical applications. J. Control. Release 2015, 200, 138-157. [CrossRef] [PubMed]

(C) 2016 by the authors; licensee MDPI, Basel, Switzerland. This article is an open access article distributed under the terms and conditions of the Creative Commons Attribution (CC-BY) license (http://creativecommons.org/licenses/by/4.0/). 